\title{
A striking, critically endangered, new species of hillstar (Trochilidae: Oreotrochilus) from the southwestern Andes of Ecuador
}

Sornoza-molina, Francisco; Freile, Juan F.; Nilsson, Jonas; Krabbe, Niels; Bonaccorso, Elisa

Published in:

The Auk: Ornithological Advances

DOI:

10.1642/AUK-18-58.1

Publication date:

2018

Document version

Publisher's PDF, also known as Version of record

Document license:

CC BY-NC

Citation for published version (APA):

Sornoza-molina, F., Freile, J. F., Nilsson, J., Krabbe, N., \& Bonaccorso, E. (2018). A striking, critically endangered, new species of hillstar (Trochilidae: Oreotrochilus) from the southwestern Andes of Ecuador. The Auk: Ornithological Advances, 135(4), 1146-1171. https://doi.org/10.1642/AUK-18-58.1 


\section{A striking, critically endangered, new species of hillstar (Trochilidae: Oreotrochilus) from the southwestern Andes of Ecuador}

Author(s): Francisco Sornoza-Molina, Juan F. Freile, Jonas Nilsson, Niels Krabbe, and Elisa Bonaccorso Source: The Auk, 135(4):1146-1171.

Published By: American Ornithological Society

https://doi.org/10.1642/AUK-18-58.1

URL: http://www.bioone.org/doi/full/10.1642/AUK-18-58.1

BioOne (www.bioone.org) is a nonprofit, online aggregation of core research in the biological, ecological, and environmental sciences. BioOne provides a sustainable online platform for over 170 journals and books published by nonprofit societies, associations, museums, institutions, and presses.

Your use of this PDF, the BioOne Web site, and all posted and associated content indicates your acceptance of BioOne's Terms of Use, available at www.bioone.org/page/terms_of_use.

Usage of BioOne content is strictly limited to personal, educational, and non-commercial use. Commercial inquiries or rights and permissions requests should be directed to the individual publisher as copyright holder. 


\title{
A striking, critically endangered, new species of hillstar (Trochilidae: Oreotrochilus) from the southwestern Andes of Ecuador
}

\author{
Francisco Sornoza-Molina, ${ }^{1}$ Juan F. Freile, ${ }^{2,3 *}{ }^{3}$ Jonas Nilsson, ${ }^{2,4}$ Niels Krabbe, ${ }^{5}$ and Elisa Bonaccorso ${ }^{6,7 *}$ \\ ${ }^{1}$ Instituto Nacional de Biodiversidad, Quito, Ecuador \\ ${ }^{2}$ Comité Ecuatoriano de Registros Ornitológicos (CERO), Tumbaco, Ecuador \\ ${ }^{3}$ Instituto BIOSFERA, Universidad San Francisco de Quito, Cumbayá, Ecuador \\ ${ }^{4}$ Wildsumaco Lodge, Cumbayá, Ecuador \\ 5 Zoological Museum, University of Copenhagen, Denmark \\ ${ }^{6}$ Universidad San Francisco de Quito, Instituto BIOSFERA, Laboratorio de Biología Evolutiva, and Colegio de Ciencias Biológicas y \\ Ambientales, Cumbayá, Ecuador \\ ${ }^{7}$ Centro de Investigación de la Biodiversidad y Cambio Climático, Universidad Tecnológica Indoamérica, Quito, Ecuador \\ * Corresponding authors: Juan F. Freile, jfreileo@yahoo.com; Elisa Bonaccorso, ebonaccorso@usfq.edu.ec
}

Submitted April 10, 2018; Accepted July 22, 2018; Published September 26, 2018

\begin{abstract}
We describe a new species of the genus Oreotrochilus from the southwestern Andes of Ecuador. The new species is most similar in adult male plumage to O. stolzmanni and O. chimborazo. However, male and female show unique combinations of plumage characters that are likely to act as social signals. Phylogenetic analyses based on mitochondrial DNA indicate that this new taxon is closely related to $O$. stolzmanni and O. melanogaster, whereas genetic distances and preliminary comparisons of vocalizations suggest a sister relationship with $O$. stolzmanni. The geographic distribution of the new species seems to be restricted to cordillera Chilla-Tioloma-Fierro Urcu, in the southwestern highlands of Ecuador, an area historically poorly explored by ornithologists. Thus, based on its restricted distribution, apparently low population size, and lack of protection of its habitat, we evaluate it as critically endangered.
\end{abstract}

Keywords: Andes, Oreotrochilus, southwest Ecuador, sp. nov., Trochilidae

\section{Una sorprendente y críticamente amenazada especie nueva de estrella (Trochilidae: Oreotrochilus) de los Andes suroccidentales de Ecuador}

\section{RESUMEN}

Describimos una nueva especie del género Oreotrochilus de los Andes suroccidentales de Ecuador. Esta nueva especie se asemeja en plumaje de macho adulto a O. stolzmanni y O. chimborazo. Sin embargo, macho y hembra muestran una combinación única de características de plumaje que probablemente actúan como señales sociales. Los análisis filogenéticos basados en ADN mitocondrial muestran que la nueva especie está más emparentada con 0 . stolzmanni y O. melanogaster, mientras que las distancias genéticas y un análisis preliminar de vocalizaciones sugieren que es especie hermana de $O$. stolzmanni. La distribución geográfica de esta nueva especie está al parecer confinada a las cordilleras de Chilla-Tioloma-Fierro Urcu, en los Andes del suroeste de Ecuador, en un área históricamente poco explorada desde el punto de vista ornitológico. En base a su distribución muy restringida, aparente bajo tamaño poblacional y la falta de protección en sus hábitats, la calificamos como críticamente amenazada.

Palabras clave: Oreotrochilus, sp. nov., Trochilidae, Andes, suroccidente de Ecuador

\section{INTRODUCTION}

Hummingbirds represent one of the most spectacular avian radiations of the New World. With more than 340 species (Clements et al. 2017), they occur from sea level up to 5,000 $\mathrm{m}$ a.s.l. in a range of habitats as different as tropical rain, deciduous, and cloud forests, Andean shrub, puna, paramo, mangrove, and desert oasis (Schuchmann and Bonan 2017). Hillstars of the genus Oreotrochilus are peculiar among hummingbirds because of their preference for high-elevation habitats along the Andes, among the highest in the Trochilidae, which is accompanied by behavioral (Pearson 1953, Carpenter 1976) and physiological (French and Hodges 1959, Carpenter 1974) adaptations to low temperatures. Their geographic range spans from extreme southern Colombia to southern Chile and Argentina, occupying paramo environments near the equator, and puna and arid plateaus southwards (Schuchmann and Bonan 2017). 
According to Remsen et al. (2018), the genus Oreotrochilus includes 5 species: O. chimborazo (extreme southern Colombia to south central Ecuador); O. estella (extreme southern Ecuador to northern and central Peru, and southern Peru to northern Chile, Bolivia, and northern Argentina); O. melanogaster (south central Peru); O. adela (Bolivia to extreme northern Argentina); and O. leucopleurus (extreme southern Bolivia, Argentina, and Chile) (Schuchmann and Bonan 2017). The monophyly of the genus is well established but the status and validity of some taxa have been debated. Fjeldså and Boesman (2017) consider the northern populations of O. estella (O. estella stolzmanni) from Ecuador, northern and central Peru as a separate species, based on plumage differences. This proposal has been considered as potentially valid by Clements et al. (2017) and Remsen et al. (2018), based on molecular evidence showing that O. estella stolzmanni is more closely related to $O$. melanogaster than to $O$. estella estella (McGuire et al. 2014). Further, O. chimborazo and O. leucopleurus have been regarded as subspecies of O. estella (Zimmer 1951), whereas O. estella bolivianus has also been ranked as full species (Peters 1945). Here, we adopt the classification of Remsen et al. (2018), but recognize O. stolzmanni as a valid species (as per Fjeldså and Boesman 2017).

Recent fieldwork in the highlands at the border of El Oro and Loja provinces, southwest Ecuador, revealed the presence of an undescribed taxon of Oreotrochilus. Herein, we describe this new taxon, assess its evolutionary relationships with other species of Oreotrochilus, and discuss potential scenarios that led to the evolutionary origin of this species. Finally, we assess its conservation status following UICN (2012) criteria.

\section{METHODS}

Following the conceptual framework developed by Simpson (1951), Wiley (1978), and de Queiroz (2007), species are defined as segments of separately evolving metapopulation lineages. As operational criteria for delimiting species (de Queiroz 2007), we assess the morphological diagnosability of the new taxon and revise other lines of evidence (i.e. genetic, vocal, ecological) that may indicate evolutionary independence and reproductive isolation from other taxa. Specific details of our methods are provided below.

\section{Fieldwork}

On April 12, 2017, during a brief visit to the paramos of Cerro de Arcos, El Oro province, southwest Ecuador (see coordinates below), F.S.M. observed and photographed what seemed to be an immature male of an Oreotrochilus hummingbird, apparently different from other Oreotrochilus described to date. Further photographs taken on
May 7, 2017, by F.S.M. confirmed that this Oreotrochilus was not assignable to any known taxon in the genus. Later, on May 22-26, 2017, F.S.M., J.F.F., and J.N. visited the same locality with the aim to collect specimens of this unique population. Capturing effort consisted of 9 mist nets $(6 \times 3 \mathrm{~m}$ and $9 \times 3 \mathrm{~m} ; 2 \mathrm{~mm}$ mesh) opened during 3 full days, 0630 hours through 1730 hours. A second expedition to the area was undertaken on July 10-13, 2017, by F.S.M. and J.N. Field observations were made in the northern part of Cordillera de Chilla (July 10), as well as west of Guanazán, in Cordillera de Tioloma (July 11). On July 13, F.S.M. and J.N. visited a Chuquiraga jussieui stand $3.9 \mathrm{~km}$ E of Refugio de Cerro de Arcos, setting up 5 mist nets $(12 \times 3 \mathrm{~m}, 2 \mathrm{~mm}$ mesh) that were opened from 1000 hours through 1600 hours. Additionally, on June 59, 2017, J.N. visited the east-central region of the Cordillera de Tioloma, making field observations only, and F.S.M. visited 5 localities along the paramos of Lagunillas-Piura-Podocarpus (along the continental divide of the Andes) and one at the Cuenca-Oña road (between the Girón and León rivers) in search of the new taxon. Finally, on April 7-9, 2018, F.S.M. and N.K. obtained sound recordings and photographs of the new taxon in and near Cerro de Arcos (including the second collecting locality), and of O. stolzmanni above Jimbura, in Zamora-Chinchipe province. Here, we also present observations from 2 localities along the paramos of Azuay-Morona-Zamora, gathered by Carlos A. Rodríguez-Saltos.

Before preparing the captured individuals as study skins, we preserved tissue from the pectoral muscle and liver in 95\% ethanol, and preserved the stomach contents in 70\% ethanol. To obtain behavioral data, 3 camera traps (Plotwatcher Pro, Columbus, Georgia, USA) were installed in front of flowering patches of Chuquiraga jussieui-the preferred plant of Oreotrochilus in Ecuador (Ortiz-Crespo and Bleiweiss 1982) - and other plant species. Cameras captured shooting records every $1 \mathrm{~s}$ and footage was analyzed using Motion Meerkat software (Weinstein 2015). Additional photographs were secured, as well as sound recordings, field observations on behavior, descriptions of habitats, and a collection of plants for identification at local herbaria.

\section{Morphological Data}

Specimens of the new taxon were compared to specimens of all taxa in the genus Oreotrochilus, with emphasis on $O$. stolzmanni, O. estella, and O. chimborazo deposited at Museo Ecuatoriano de Ciencias Naturales (MECN), Museo de Zoología, Pontificia Universidad Católica del Ecuador (QCAZ), Natural History Museum, Tring (NHM), and Senckenberg Natural History Museum, Frankfurt (SNM). Additional comparisons were performed with series of photographs taken from specimens of O. estella 
and O. stolzmanni deposited at Academy of Natural Sciences of Philadelphia (ANSP) and Natural History Museum of Denmark, University of Copenhagen (NHMD). Original descriptions of Oreotrochilus were reviewed, when relevant (Gould 1847), as well as species accounts and illustrations (Fjeldså and Krabbe 1990, Ridgely and Greenfield 2001, Schulenberg et al. 2007, McMullan 2016, Schuchmann and Bonan 2017) and online photographs (www.hbw.com; neotropical.birds. cornell.edu). Specimens were photographed individually and in species series, and photographs of outer tail feathers were taken of specimens whose preparation permitted harmless manipulation. Specimens studied are listed in Appendix A.

We made quantitative morphometric comparisons with all known species of Oreotrochilus. Analyses were based on measurements of bill length from base of feathers, wing chord, tail length, and width of the 2 outermost rectrices. Additionally, information of sex, age, and weight was recorded, based on field notes and specimen labels. Before performing statistical comparisons, we applied the ShapiroWilk statistic test to evaluate the normality of individual measurements (i.e. wing, bill, tail, rectrices 1 and 2) on species with more than 12 specimens per sex, separating specimens by species and by sex. We then performed 2tailed Student's $t$-tests to compare measurements between sexes within each species. To explore potential morphometric differences between species, we applied a principal component analysis (PCA) on the correlation matrix of all 5 measurements. We could not control for body weight, since this measurement was missing from most specimen labels, especially those of historical specimens. All statistical analyses were performed in STATISTICA 8.0 (StatSoft Inc. 2007).

\section{Evolutionary Relationships}

We used samples of pectoral tissue from 4 individuals of the new taxon for molecular phylogenetic analyses. We sequenced the mitochondrial gene NADH dehydrogenase subunit 2 (ND2), which has been widely used on molecular studies of hummingbirds in general (McGuire et al. 2008) and Oreotrochilus, in particular (RodríguezSaltos and Bonaccorso 2016). Genomic DNA extraction, amplification, sequencing, and sequence edition protocols follow Rodríguez-Saltos and Bonaccorso (2016). Obtained sequences were compared with those available on GenBank (https://www.ncbi.nlm.nih.gov/genbank/) of all other Oreotrochilus except O. adela. Based on the most recent hypothesis of hummingbird relationships (McGuire et al. 2008), we selected Ramphomicron microrhynchum and Chalcostigma herrani as outgroup species. Sequences were aligned in Clustal X2 (Larkin et al. 2007) and translated into amino acids in Mesquite 3.2 (Maddison and Maddison 2017) to verify the absence of stop codons. We used PartitionFinder2 (Lanfear et al. 2016) to determine the most appropriate partition scheme for the dataset-which turned out to be HKY + G, HKY, and GTR for the first, second, and third codon positions, respectively. Phylogenetic trees were obtained using maximum likelihood (ML) and Bayesian analyses. ML trees were estimated using GARLI 2.0 (Zwickl 2006), running 20 independent analyses with default settings, and selecting the tree with the maximum value of log likelihood. Bootstrap support (1,000 pseudoreplicates) was assessed running one replicate per search. Bayesian analyses were conducted in MrBayes 3.2 (Ronquist and Huelsenbeck 2003) using a random starting tree, 4 simultaneous Markov chains run for 1,000,000 generations, sampling every 1,000 trees, discarding the first $20 \%$ of trees as burn-in, and combining the remaining into a 50\% majority-rule consensus tree. We also obtained a statistical parsimony network in TCS 1.21 (Clement et al. 2000) among the new taxon and its more closely related species. Finally, uncorrected genetic pairwise distances were calculated in PAUP v.4.0a109 (Swofford 2009) in order to provide a framework for comparisons of genetic differences among species of Oreotrochilus.

\section{Potential Distribution}

As a preliminary exploration of the potential distributional range of the new taxon, we obtained an Ecological Niche Model (ENM). For this analysis we used the coordinates of 5 known occurrence localities (all separated by at least 4 $\mathrm{km}$ ) and the 19 WorldClim 1.4 variables (www.worldclim. org; Hijmans et al. 2005) at $30 \mathrm{~s}$ resolution $(\sim 1 \times 1 \mathrm{~km}$ pixel size in Ecuador). Model estimation was achieved with Maxent 3.3.3k (Phillips et al. 2006) using default settings and logistic output. As background, we used 10,000 random points taken from the portion of the Andes above 1,000 m a.s.l., between the Jubones and Catamayo rivers. Significance of model predictions was assessed with the Pearson et al. (2007) jackknife validation approach, which is particularly suited for models derived from small numbers of occurrence records. Model predictions were projected to encompass areas between southern Ecuador and northern Peru, in order to explore the extent of the potential distribution of the species in a broader geographical region.

\section{Bioacoustics}

Pitch, duration, relative volume, note shape, and cadence of vocalizations were determined and compared among most Oreotrochilus taxa, depending on availability of audio recordings, and oscillograms and sonograms prepared with the sound-editing program CoolEditPro (Syntrillium Software, Scottsdale, Arizona, USA). The recordings analyzed are listed in Appendix B. 
A

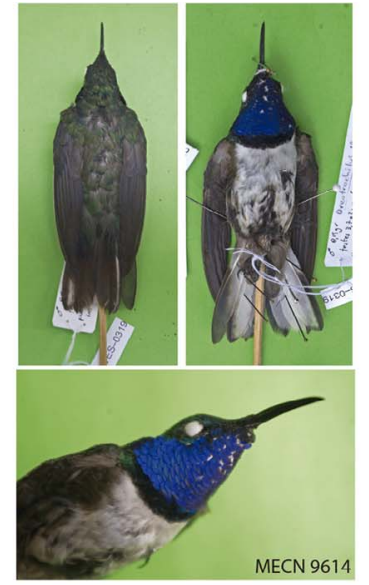

B

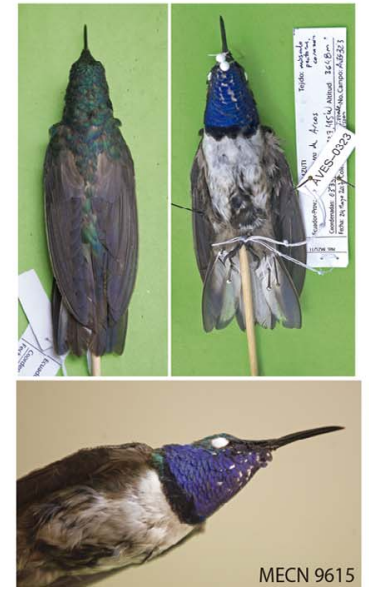

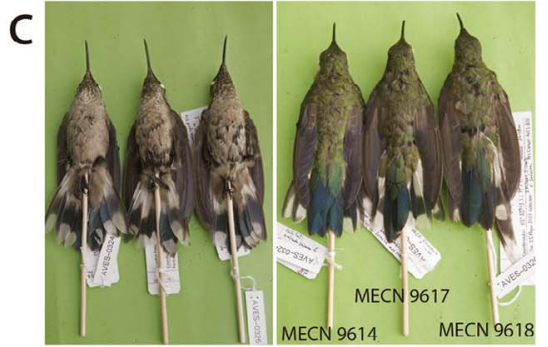
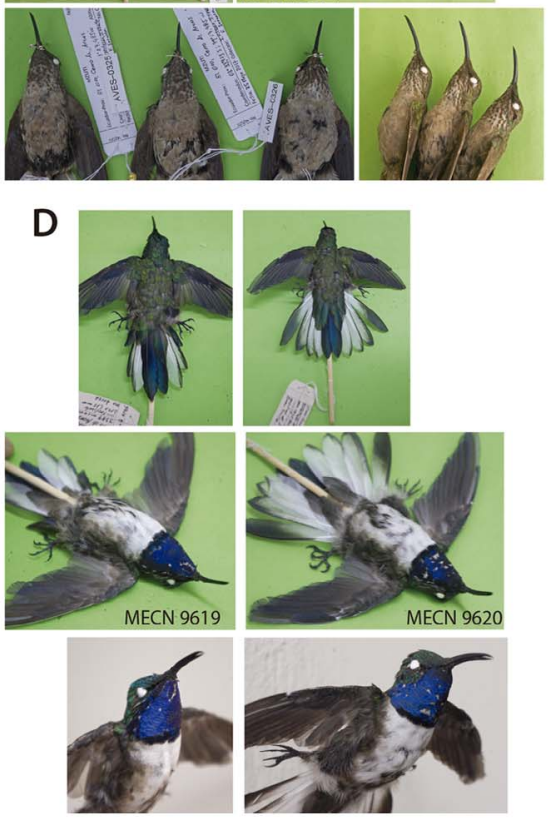
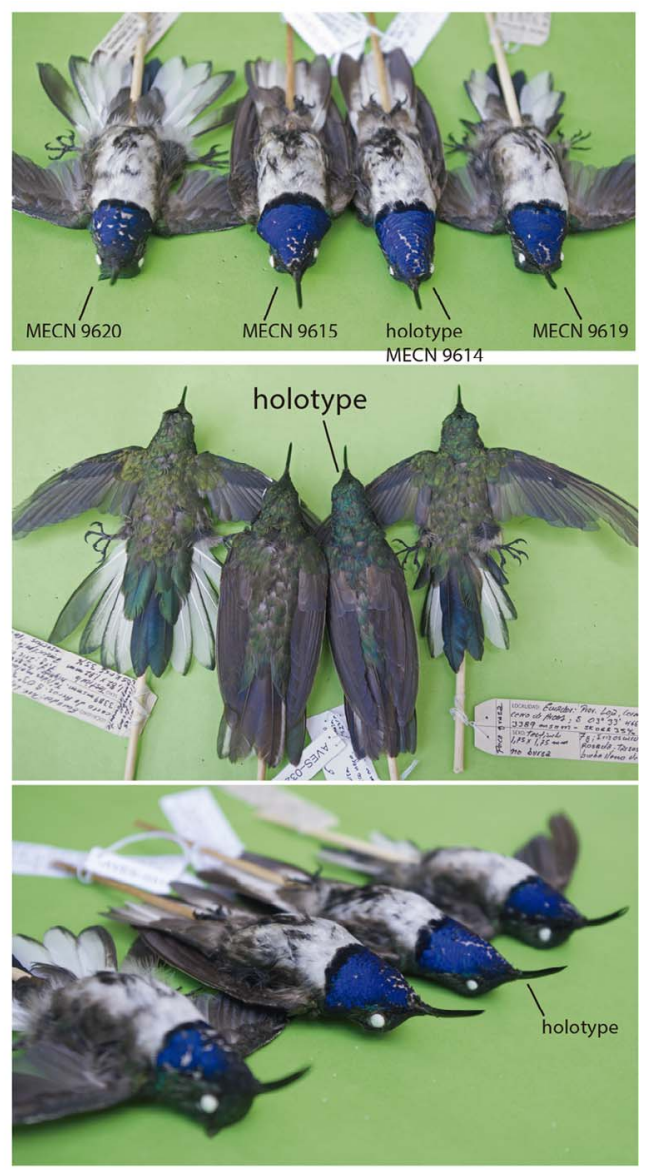

FIGURE 1. Series of Oreotrochilus cyanolaemus species nova collected at Cerro de Arcos, El Oro province, southwest Ecuador, May 23, 2017: (A) holotype, (B) paratopotype male, (C) paratopotype females, (D) paratype males.

\section{RESULTS}

Fieldwork resulted in the collection of 5 specimens at $1 \mathrm{~km}$ W of Refugio de Cerro de Arcos (2 adult males, 3 females) and 2 adult males $3.9 \mathrm{~km}$ E of Refugio de Cerro de Arcos (see below). A combination of unique plumage characters studied in collected specimens and live individuals distinguish the Oreotrochilus population from Cerro de Arcos and vicinities as a new taxon, for which we provide the following description:

\section{Oreotrochilus cyanolaemus sp. nov.}

Blue-throated Hillstar

Estrella de Garganta Azul (Spanish)

Holotype. Study skin MECN-9614 (Figure 1A); adult male (testes $3.7 \times 3 \mathrm{~mm}$, no bursa fabricii), $1 \mathrm{~km} \mathrm{~W}$ of Cerro de Arcos, El Oro province $\left(3.5662^{\circ} \mathrm{S}, 79.4580^{\circ} \mathrm{W}\right.$; Figure 2A); 3,648 m a.s.l.; collected on May 23, 2017, by F. Sornoza-Molina, J. Freile, and J. Nilsson; prepared by F. Sornoza-Molina; field catalogue number AVES-0319; GenBank accession number MH543324.
Generic Placement. The new species is placed in the genus Oreotrochilus Gould 1847, on the basis of morphological and molecular data. The main diagnostic morphological traits of Oreotrochilus, as originally described (Gould 1847:10), are shared by the new species. Analyses of ND2 place it as a close relative to other Oreotrochilus, making generic placement unambiguous (Figure 3).

Diagnosis. The following combination of characters are diagnostic for male Oreotrochilus cyanolaemus from other Oreotrochilus species (Figure 4): (1) ultramarine blue throat, (2) emerald green head with blue green terminal tips, (3) emerald green upperparts with blue green terminal tips, (4) narrow and faint emerald green terminal tips to throat feathers. Females are distinguished by the following characters: (1) dusky grayish chin and upper throat contrasting with whitish lower throat, (2) emerald green head with blue green terminal tips, (3) emerald green upperparts with faint blue green shine, especially on the rump.

Comparisons with Similar Taxa. The new species is most similar in male plumage to Oreotrochilus stolzmanni 

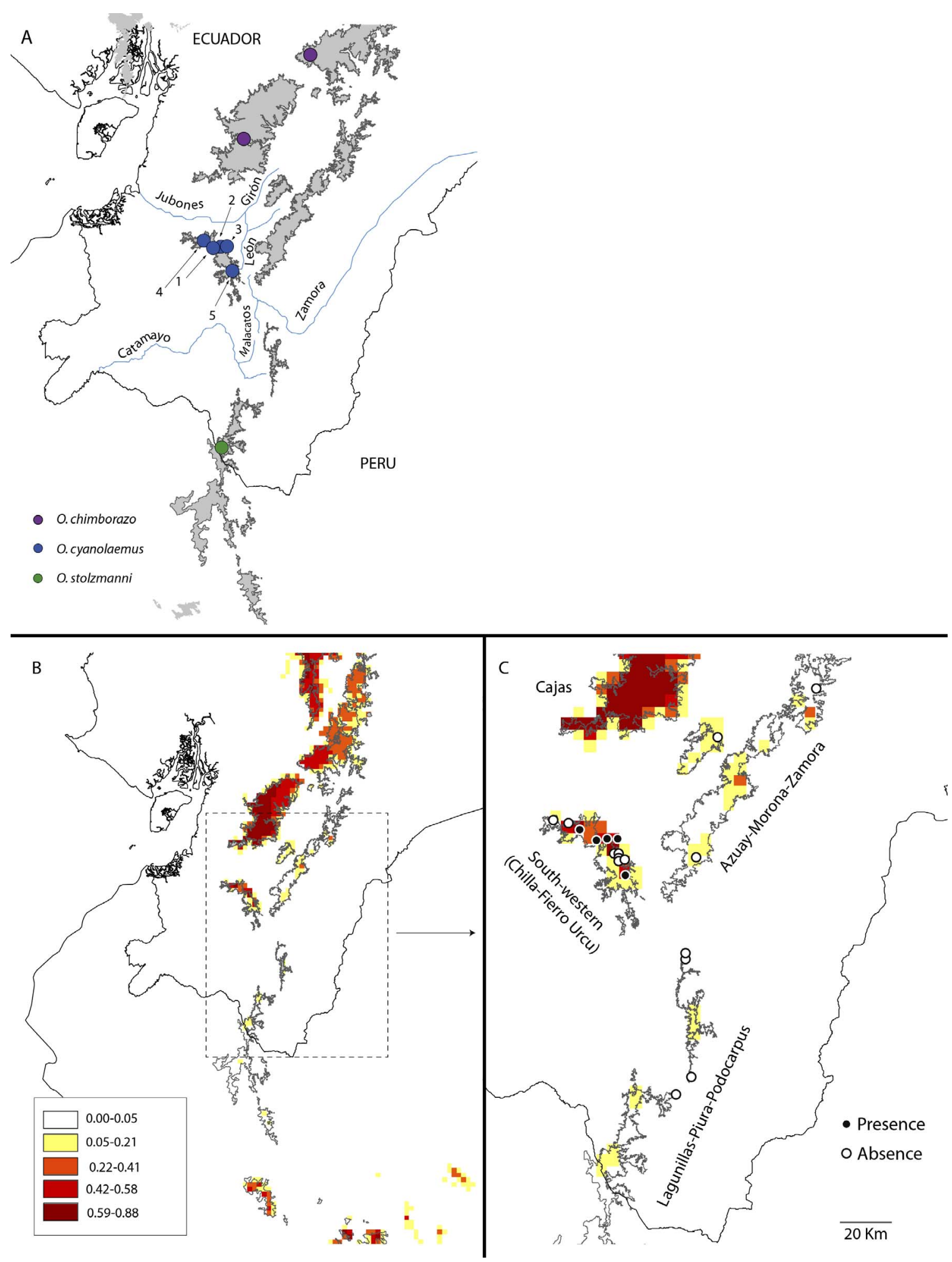

FIGURE 2. Distribution of Oreotrochilus cyanolaemus species nova in southwest Ecuador. (A) Occurrence localities: (1) Cerro Arcos, El Oro province; (2) base of Cerro de Arcos on the road to Celén, 3.9 km E of Cerro de Arcos, Loja province; (3) La Capilla, near laguna de Chinchilla, Loja province; (4) 7.5 km S of Guanazán, El Oro province; (5) Fierrourco, Loja province. (B) Potential distribution; warmer colors indicate higher probability of presence. (C) Presence (black circles) and absence (white circles) localities identified to date. 


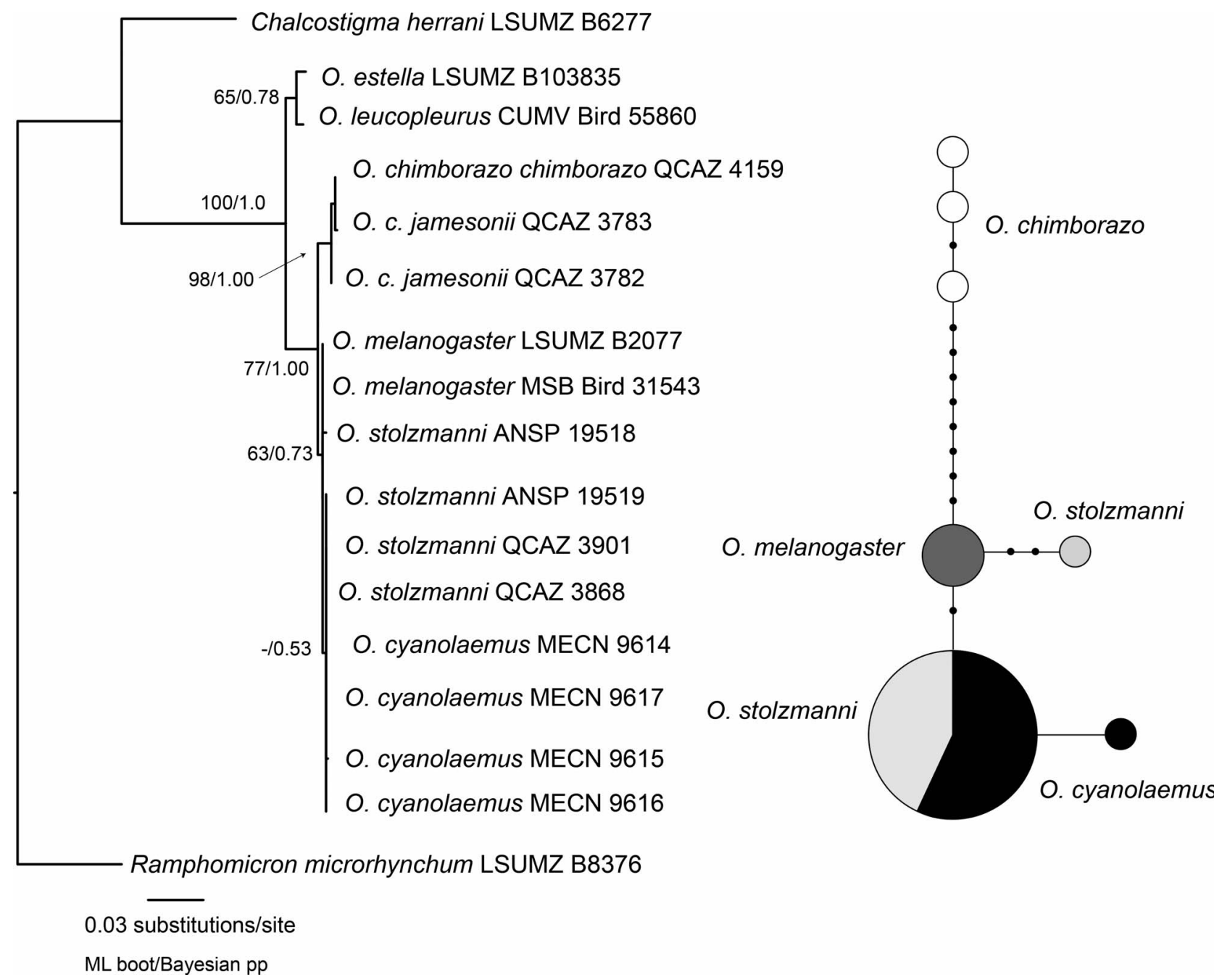

FIGURE 3. Phylogenetic tree of species in Oreotrochilus based on maximum likelihood (ML support and Bayesian posterior probabilities shown on major nodes) and haplotype network for O. cyanolaemus and closely related species.

and O. chimborazo, with which it shares a black throat collar, white breast to vent, narrow black longitudinal mid stripe in belly that does not reach the collar, greenish to buffy gray flanks to crissum, and metallic blue to greenish blue upper surface of tail. However, it differs from $O$. chimborazo in the absence of deep purple hood (O. c. jamesonii) or purple hood and turquoise green throat patch (O. c. chimborazo); the new species also has greener to blue-green dorsal parts, not as dull olive green as both subspecies of $O$. chimborazo.

The most similar Oreotrochilus taxon is O. stolzmanni, with which it shares an overall pattern of emerald green crown, shining throat, and other characters aforementioned for O. stolzmanni and O. chimborazo. However, throat patch in O. stolzmanni is shining green with narrow bronzy tips in a few feathers, and a slight bluish sheen on the sides at certain angles. Entire upperparts of $O$. cyanolaemus are emerald green to emerald blue green, greener and brighter than in O. stolzmanni; O. cyanolaemus also lacks the bronzy sheen on the upperparts of $O$. stolzmanni, and the crown is greener, not bronze green as in O. stolzmanni.

Oreotrochilus stolzmanni and O. cyanolaemus have similar shape of the outermost rectrices, which are broader-based, with very narrow outer web from mid part towards tip, and blunt tip. Outermost rectrices in $O$. chimborazo also have very narrow outer web, but are narrower and straighter throughout than in O. cyanolaemus and O. stolzmanni, whilst in the remaining species the outer rectrices have outer webs of uniform width and less blunt-shaped tips. Outer rectrices in some specimens of $O$. adela and especially $O$. leucopleurus are more curved. Intraspecific and interspecific variation in shape of outer rectrices needs further study of a larger sample size, especially in O. cyanolaemus, O. stolzmanni, O. melanogaster, and O. estella. 


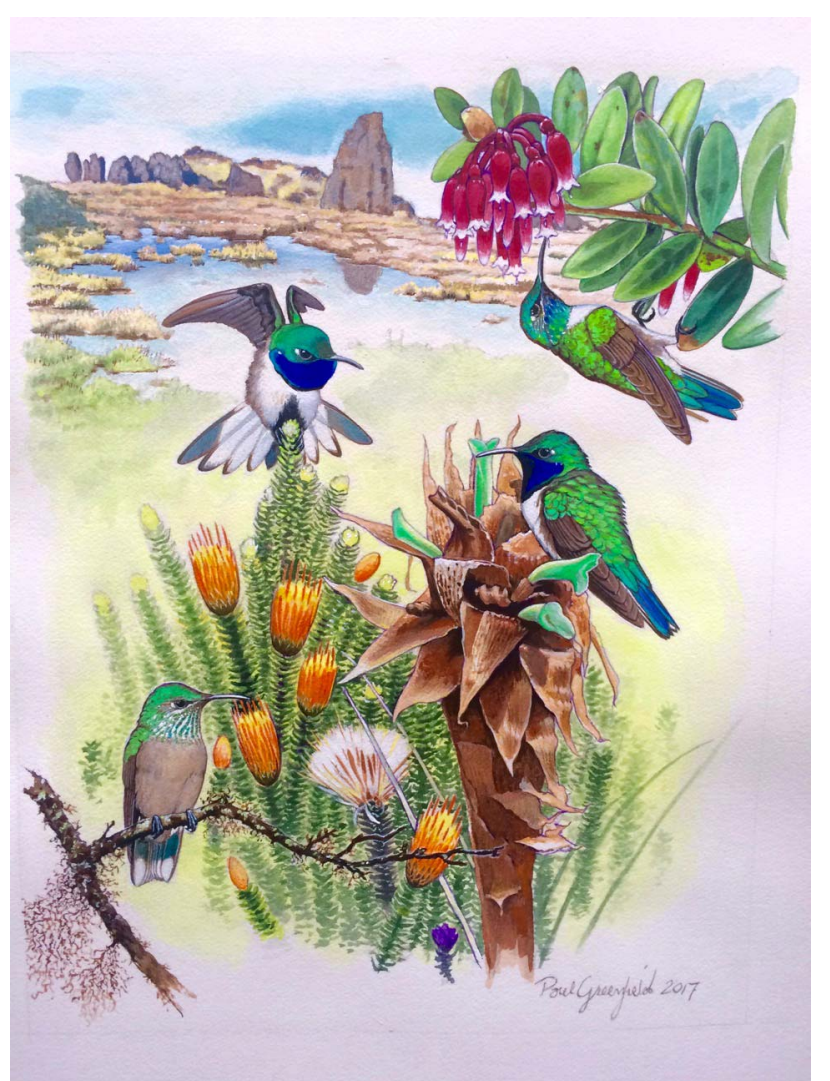

FIGURE 4. Adult male (above left, center right), adult female (below), and immature male (above right) Oreotrochilus cyanolaemus species nova at the type locality, El Oro province, southwest Ecuador. Illustration courtesy of Paul Greenfield (2017).

Differences from the remaining Oreotrochilus species are more marked, with ultramarine blue throat and emerald to blue green upperparts being the most remarkable in male plumage. Besides throat color, O. cyanolaemus differs from O. estella by a black mid-belly stripe (brownish in O. estella) and green upperparts (dull bronzy olive in O. estella). In $O$. leucopleurus, the black mid-belly stripe is much broader than in O. cyanolaemus, throat is shining lime green, the upperparts are duller bronzy green, and the outermost tail feathers more arched. Oreotrochilus cyanolaemus is strikingly different from $O$. melanogaster, which has green throat, velvet black lower underparts, with orange buff flanks, and all rectrices greenish black. Oreotrochilus adela has chestnut flanks and breast sides, black central stripe that extends from lime green gorget to crissum, and all rectrices are blackish and buff. Characters like color of upperside of tail (steel blue to metallic greenish blue), color of glossy feathers in black throat collar and mid-belly stripe (bright green to bright blue), and extent of white on base of throat feathers are rather variable within the genus and need further attention.
Female Oreotrochilus cyanolaemus is the only Oreotrochilus with dark grayish chin and throat with sparse metallic green spots; females of all other species in the genus have whitish chins. The amount and pattern of green spots in throat is variable across the genus, but $O$. cyanolaemus has bluer green spots in throat sides than all other Oreotrochilus taxa. Lower underparts in O. cyanolaemus are duller and darker grayish buff than in $O$. stolzmanni, O. estella, O. melanogaster, and O. leucopleurus, being closer to both subspecies of O. chimborazo. Upperparts are emerald green, greener than most congeners, with much less bronzy shine than $O$. chimborazo and lacking the dull bronzy tone of O. estella, O. leucopleurus, and $O$. adela. It is closer in tone to O. stolzmanni and $O$. melanogaster, but bluer green overall, with less bronzy forecrown and less bronzy shine overall.

Comparative photographs of museum specimens of all Oreotrochilus species are found in Appendix Figures 7-12; Appendix Figure 13 compares O. cyanolaemus and its putative closest relative: O. stolzmanni. Living individuals photographed at the type locality are presented in Appendix Figure 14.

Description of the Holotype. Color nomenclature (capitalized colors) follow Ridgway (1912). Forehead to hindcrown glittering emerald green (between Killarney and Motmot Green), with blue-green reflections (approaching Methyl Blue). Nape, mantle, lower back, upperwing coverts, and rump glittering emerald green (approaching Killarney, Motmot Green, and Vivid Green), with narrow blue-green edges in several feathers (between Leitch's and Paris Blue) and some bronzy green reflections; uppertail coverts emerald blue-green (between Leitch's and Paris Blue). Dorsal surface of central rectrices steely (blackish) blue (Dusky Dull Violet-Blue to Bluish Black) with little glitter. All remiges and greater upperwing coverts dull blackish, with a faint steely blue sheen in some angles (Dusky Dull Violet-Blue to Bluish Black); outer web of outermost primaries with a very narrow whitish edge.

Chin and throat feathers glittering ultramarine blue (approaching Lyons Blue), with broad, pure white bases and a narrow blackish line separating ultramarine blue from white; throat feathers have narrow and faint emerald green terminal tips (between Peacock Green and Killarney Green). Feathers in throat sides are longer than in central throat and chin. Velvet black throat collar (Black), feathers with shinier blue-green mid portion that provides a blue sheen in some angles, and narrow white bases. Breast to belly sides dull white, feathers with blackish bases. Narrow longitudinal stripe in mid belly is velvet black (Black), some feathers with shinier blue-green mid portion that provide a blue-green sheen; bases of feathers forming the central stripe are dull white. Breast sides to flanks greenish gray (between Grass Green, Cress Green, and Deep Dull Yellow-Green 1), with green sheen in some angles. 
Undertail coverts dull grayish buff (between Warbler Green and Yellowish Oil Green). Ventral surface of tail dull white in rectrices 3 and 4, both with narrow, dull blackish blue edges to outer webs (Dusky Dull Violet-Blue to Bluish Black); rectrices 2 with dull blackish blue tip and most outer webs, rectrices 1 with entire outer half dull blackish blue. Central rectrices entirely blackish blue.

Bill is black with yellowish tomia, legs and claws also black, eyes are dark brown. Measurements are as follows: culmen $=18.3 \mathrm{~mm}$; wing chord $=70 \mathrm{~mm}$; tail $=49.4 \mathrm{~mm}$; right rectrix 1 (outer) $=7.6 \mathrm{~mm}$; right rectrix $2=8 \mathrm{~mm}$; weight $=8.15 \mathrm{~g}$.

Paratopotypes. Study skin MECN-9615 (Figure 1B); adult male (testes $4.5 \times 3.2 \mathrm{~mm}$, no bursa fabricii); collected May 24, 2017, by F. Sornoza-Molina, J. Freile, and J. Nilsson; prepared by F. Sornoza-Molina; field catalogue number AVES 0323; GenBank accession number MH543326.

Study skin MECN 9616 (Figure 1B); adult female (ovum $5.4 \times 2.7 \mathrm{~mm}$, no bursa fabricii). Collected on May 25, 2017, by J. Nilsson, J. Freile, and F. Sornoza-Molina; prepared by F. Sornoza-Molina; field catalogue number AVES 0324; GenBank accession number MH543327.

Study skin MECN 9617 (Figure 1C); presumed immature female (ovum $3.7 \times 2.1 \mathrm{~mm}$, no bursa fabricii). Collected on May 25, 2017, by J. Nilsson, J. Freile, and F. Sornoza-Molina; prepared by F. Sornoza-Molina; field catalogue number AVES 0325; GenBank accession number MH543325.

Study skin MECN 9618 (Figure 1C); adult female (ovum $5.2 \times 3.8 \mathrm{~mm}, 30$ follicles smaller than $1 \mathrm{~mm}$, no bursa fabricii). Collected on May 25, 2017, by J. Nilsson, J. Freile, and F. Sornoza-Molina; prepared by F. Sornoza-Molina; field catalogue number AVES 0326 (Figure 1C).

Photographs of live individuals secured at the collection localities are archived at Macaulay Library, Cornell University (ML105920601, ML105921501, ML105921711, ML105922381), and the Internet Bird Collection (IBC 1502180, 1502183-1502186, 1502189, 1502192, 1502193). Audio recordings archived at Macaulay Library (104901281, 104901351, 104901391) and Xeno-Canto (419234, 419237, 419240, 419247).

Paratypes. Study skins MECN-9619 and 9620; adult males (testes $1.75 \times 1.75 \mathrm{~mm}$ and $1.82 \times 1.82 \mathrm{~mm}$, respectively, no bursa fabricii; Figure 1D); $3.9 \mathrm{~km} \mathrm{E}$ of Refugio de Cerro de Arcos, Loja province $\left(3.5567^{\circ} \mathrm{S}\right.$, $79.4213^{\circ} \mathrm{W}$; Figure $2 \mathrm{~A}$ ); 3,374 $\mathrm{m}$ a.s.l.; collected July 13 , 2017, by J. Nilsson and F. Sornoza-Molina; prepared by F. Sornoza-Molina; field catalogue numbers FS-2377 and FS2378. Audio recordings archived at Macaulay Library (104900761, 104900901, 104900971) and Xeno-Canto (419214, 419224, 419229).

Plumage Variation. Dorsal parts in male plumage are emerald green, varying in reflections from emerald bronzy green to blue-green (approaching Rood's Blue and Hortense Blue) in one specimen (MECN 9615), which has the largest gonads. Dorsal surface of rectrices is steely (blackish) blue with little glitter in 2 specimens, including the holotype, but metallic blue green in 2 specimens (approaching Dusky Greenish Blue, Dusky Green Blue 2, and Dusky Dull Bluish Green), recalling female's tail (see below).

Extent of narrow emerald green tips to feathers of throat varies from extensive edges on throat sides and even chin in one specimen (MECN 9615) to fewer and fainter edges limited to throat. Amount of green sheen in flanks varies little, but in 2 specimens greenish gray extends more onto belly sides, leaving a narrower white portion between flanks and mid-belly stripe. Mid-belly stripe has variable amounts of blue-green feathers that provide a bright sheen. Specimen MECN 9615 has bluer and more extensive shining feathers, whereas others have faint green sheen. Undertail coverts are dull grayish buff with greener sheen in 2 specimens. There is little variation in tail pattern, resulting from narrower blackish edges of outer webs of inner rectrices, excepting central pair.

Color of dorsal parts in female plumage is glittering emerald green (between Killarney and Motmot Green), duskier on forehead, sheen varies from bluish emerald green to bronzy emerald green; uppertail coverts are bluer and brighter (between Benzol Green and Prussian Green), and dorsal surface of central rectrices has a metallic bluegreen sheen (approaching Dusky Greenish Blue, Dusky Green Blue 2, and Dusky Dull Bluish Green). Remiges and greater wing coverts are dusky, with a slight bluish sheen in some angles; outer web of outermost primaries has a very narrow whitish edge.

Chin and mid-throat feathers have grayish olive outer halves, blackish bases, whitish central portion, and a dark green distal spot, providing a dusky background (between Dark Grayish Olive and Dark Olive) to dark green spots (between Duck Green and Dark Green); throat sides are whiter. Extent of dusky in chin and throat presents some variation, with dusky extending down to lower throat and connecting with grayish buff breast in one specimen (MECN 9618), down to mid throat in specimen MECN 9617, and limited to chin and upper throat in specimen MECN 9616. Extent of grayish on chin and throat results in varying amounts of white on lower throat, more noticeable white in those specimens with less extensive dusky. Amount, extent, size, and tone of green dots in throat and malar region vary from large, blue-green dots in conspicuous rows in 2 specimens, to smaller, sparser, and greener dots in one specimen. The former 2 specimens have larger ova, suggesting that variation in size and color of throat dots is related to reproductive status. Breast, breast sides, belly, flanks, and undertail coverts are dull grayish buff (Grayish Olive to Mouse Gray), with a few 
TABLE 1. Summary of measurements $(\mathrm{mm})$ of species in the genus Oreotrochilus. We also show the results of 2-tailed Student's ttests of differences between males and females for species with more than 12 samples for each sex.

\begin{tabular}{|c|c|c|c|c|c|c|c|c|}
\hline \multirow[b]{2}{*}{ Species } & \multicolumn{3}{|c|}{ Males } & \multicolumn{3}{|c|}{ Females } & \multirow[b]{2}{*}{$t$} & \multirow[b]{2}{*}{$P$} \\
\hline & $N$ & Mean & SD & $N$ & Mean & SD & & \\
\hline \multicolumn{9}{|l|}{ Bill length } \\
\hline O. cyanolaemus & 4 & 18.70 & 0.27 & 3 & 19.83 & 0.51 & - & - \\
\hline O. stolzmanni & 11 & 19.59 & 0.84 & 8 & 19.54 & 1.32 & - & - \\
\hline O. melanogaster & 6 & 18.43 & 1.20 & 5 & 18.56 & 0.36 & - & - \\
\hline O. chimborazo & 70 & 19.91 & 0.89 & 28 & 20.16 & 0.83 & 1.29 & 0.20 \\
\hline O. estella & 27 & 20.37 & 0.93 & 15 & 20.15 & 0.63 & 0.08 & 0.41 \\
\hline O. leucopleurus & 19 & 19.40 & 1.57 & 12 & 18.81 & 0.96 & 1.17 & 0.25 \\
\hline O. adela & 7 & 26.73 & 0.70 & 4 & 26.30 & 0.83 & - & - \\
\hline \multicolumn{9}{|l|}{ Wing length } \\
\hline O. cyanolaemus & 4 & 69.13 & 3.35 & 3 & 65.83 & 0.76 & - & - \\
\hline O. stolzmanni & 12 & 71.79 & 1.90 & 8 & 68.19 & 1.31 & - & - \\
\hline O. melanogaster & 5 & 72.90 & 0.42 & 4 & 69.25 & 0.29 & - & - \\
\hline O. chimborazo & 72 & 73.49 & 1.83 & 27 & 69.26 & 2.08 & 9.86 & $<\mathbf{0 . 0 0 1}$ \\
\hline O. estella & 26 & 73.16 & 2.17 & 13 & 70.19 & 1.44 & 4.46 & $<0.001$ \\
\hline O. leucopleurus & 19 & 67.08 & 1.86 & 13 & 63.62 & 2.54 & 4.46 & $<\mathbf{0 . 0 0 1}$ \\
\hline O. adela & 8 & 65.56 & 0.56 & 4 & 65.75 & 0.96 & - & - \\
\hline \multicolumn{9}{|l|}{ Tail length } \\
\hline O. cyanolaemus & 3 & 48.97 & 0.67 & 3 & 49.20 & 0.27 & - & - \\
\hline O. stolzmanni & 12 & 50.20 & 1.86 & 8 & 49.83 & 1.66 & - & - \\
\hline O. melanogaster & 7 & 48.29 & 2.15 & 5 & 48.06 & 2.15 & - & - \\
\hline O. chimborazo & 72 & 51.73 & 2.18 & 28 & 50.20 & 1.87 & 3.28 & $<0.01$ \\
\hline O. estella & 27 & 52.20 & 2.12 & 14 & 51.04 & 2.18 & 1.64 & 0.11 \\
\hline O. leucopleurus & 20 & 46.81 & 2.12 & 13 & 45.95 & 2.95 & 0.97 & 0.34 \\
\hline O. adela & 8 & 50.53 & 1.16 & 4 & 50.58 & 1.12 & - & - \\
\hline \multicolumn{9}{|c|}{ Width of rectrix 1} \\
\hline O. cyanolaemus & 8 & 6.26 & 0.33 & 4 & 6.88 & 0.61 & - & - \\
\hline O. stolzmanni & 11 & 7.12 & 0.70 & 7 & 7.30 & 0.66 & - & - \\
\hline O. melanogaster & 5 & 6.26 & 0.52 & 4 & 6.80 & 0.74 & - & - \\
\hline O. chimborazo & 58 & 5.87 & 0.74 & 25 & 6.34 & 0.58 & 3.18 & $<0.01$ \\
\hline O. estella & 26 & 5.78 & 0.76 & 12 & 6.52 & 0.60 & 2.97 & $<0.01$ \\
\hline O. leucopleurus & 18 & 4.67 & 0.80 & 8 & 5.61 & 0.44 & - & - \\
\hline O. adela & 8 & 6.26 & 0.33 & 4 & 6.88 & 0.61 & - & - \\
\hline \multicolumn{9}{|c|}{ Width of rectrix 2} \\
\hline O. cyanolaemus & 3 & 8.53 & 0.55 & 3 & 8.83 & 0.32 & - & - \\
\hline O. stolzmanni & 11 & 8.02 & 0.83 & 7 & 8.64 & 0.83 & - & - \\
\hline O. melanogaster & 5 & 7.72 & 0.29 & 5 & 8.12 & 0.53 & - & - \\
\hline O. chimborazo & 58 & 7.50 & 0.51 & 24 & 7.89 & 0.46 & 3.23 & $<0.01$ \\
\hline O. estella & 36 & 7.96 & 0.54 & 12 & 8.26 & 0.69 & 16.44 & 0.11 \\
\hline O. leucopleurus & 17 & 6.79 & 0.63 & 7 & 6.66 & 0.41 & - & - \\
\hline O. adela & 8 & 5.98 & 0.30 & 4 & 7.03 & 0.46 & - & - \\
\hline
\end{tabular}

brighter olive green feathers on flanks and a slight green sheen on undertail coverts; ventral parts show little variation from breast to undertail coverts, and in amount of olive green in flanks. Rectrices are metallic bluish green (Dusky Greenish Blue 2 to Dusky Dull Green) with dull white bases in all but central pair, and dull white, roundshaped panels towards feather tips, variable in size and shape among feathers, but larger on outer rectrices. Tail pattern varies individually in size and shape of dull white patches.

Measurements. The Shapiro-Wilk test could not reject normality of the data for species with more than 12 samples per sex (all $P>0.05$ ). In applying the
Student's $t$-tests, we found no statistical differences in bill size between males and females of any species (Table 1). For all species, except $O$. adela, wings of males were always longer than in females, and were significantly longer in O. chimborazo, O. estella, and O. leucopleurus (all $P<0.001$ ). Difference in length of tail between males and females varied, and was significant in O. chimborazo $(P<0.01)$. Rectrix 1 was always wider in females than in males, and significantly wider in females of O. chimborazo and $O$. estella (both $P<0.01$ ). Finally, for all species except $O$. leucopleurus, rectrix 2 was wider in females than in males, and significantly wider in O. chimborazo ( $P$ $<0.01)$. 

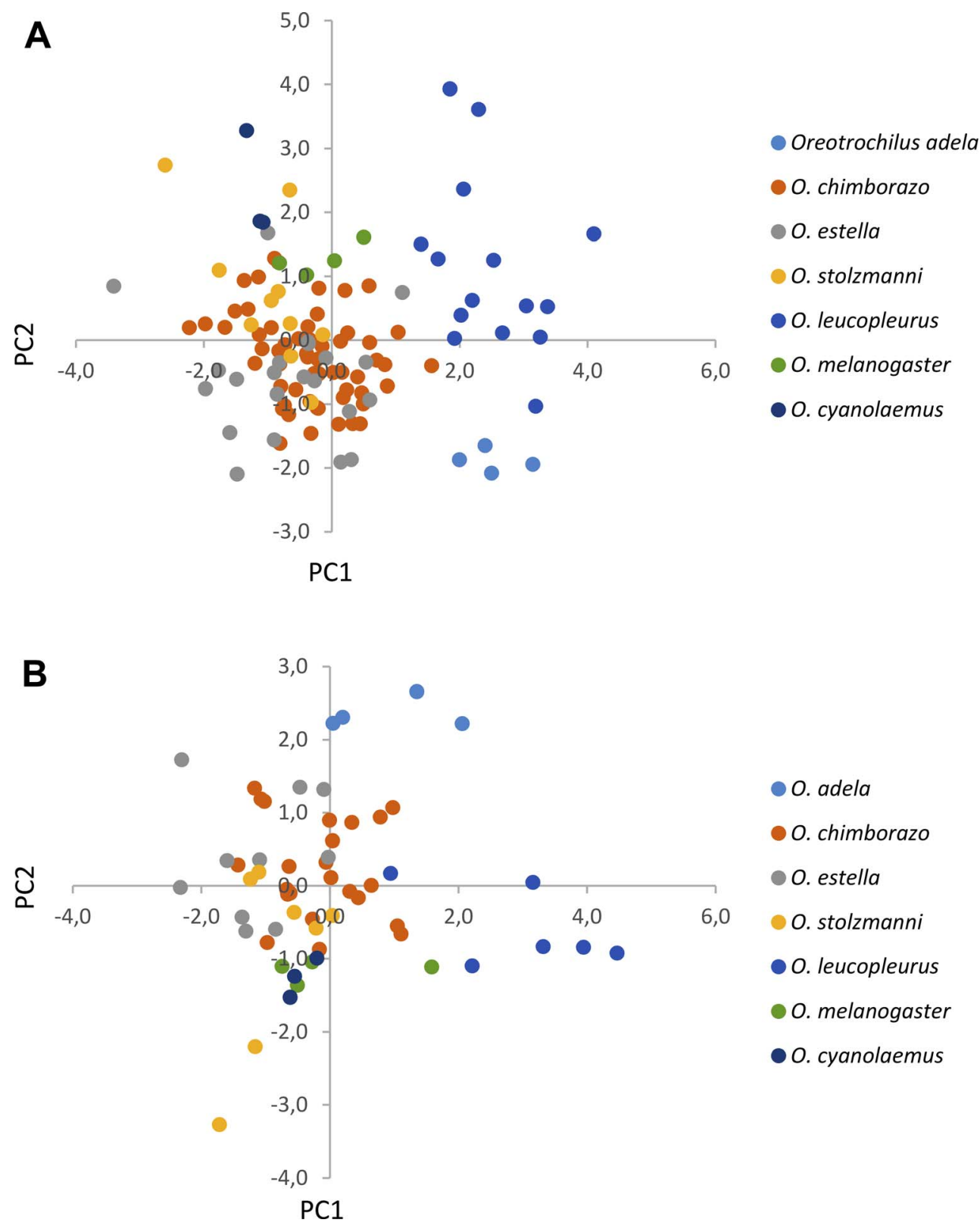

FIGURE 5. Principal component analysis of morphological measurements in males (A) and females (B) of Oreotrochilus species. PC1 and $\mathrm{PC}$, principal component 1 and 2, respectively.

Because of differences detected between sexes, PCA comparisons were performed separately in males and females (Figure 5). For males, the first 3 PCAs accounted for $87 \%$ of variation in the correlation matrix. The PC1 explained $38 \%$ of the total variation, and was negatively and significantly correlated with width of rectrix $2(r=$ $-0.84 ; t=-16.88, P<0.001)$, width of rectrix $1(r=-0.71$; $t=-10.87, P<0.001)$, and wing length $(r=-0.59 ; t=$ $-7.78, P<0.001)$. The PC2 explained $27 \%$ of the variance, and was negatively and significantly correlated with tail length $(r=-0.73 ; t=-11.49, P<0.001)$ and bill length $(r=-0.61 ; t=9.10, P<0.001)$. The analysis placed samples of $O$. cyanolaemus within the variation of $O$. stolzmanni, close to O. chimborazo and O. melanogaster, and one individual of $O$. estella. However, small sample size for $O$. cyanolaemus could be masking a greater variation in measurements. Samples of O. leucopleurus and $O$. adela clearly separated from samples of all other species. Overall, both species had narrower rectrices 1 and 2 and longer wings than the other species (PC1), but $O$. leucopleurus had shorter tails and bills than $O$. adela (PC2). 

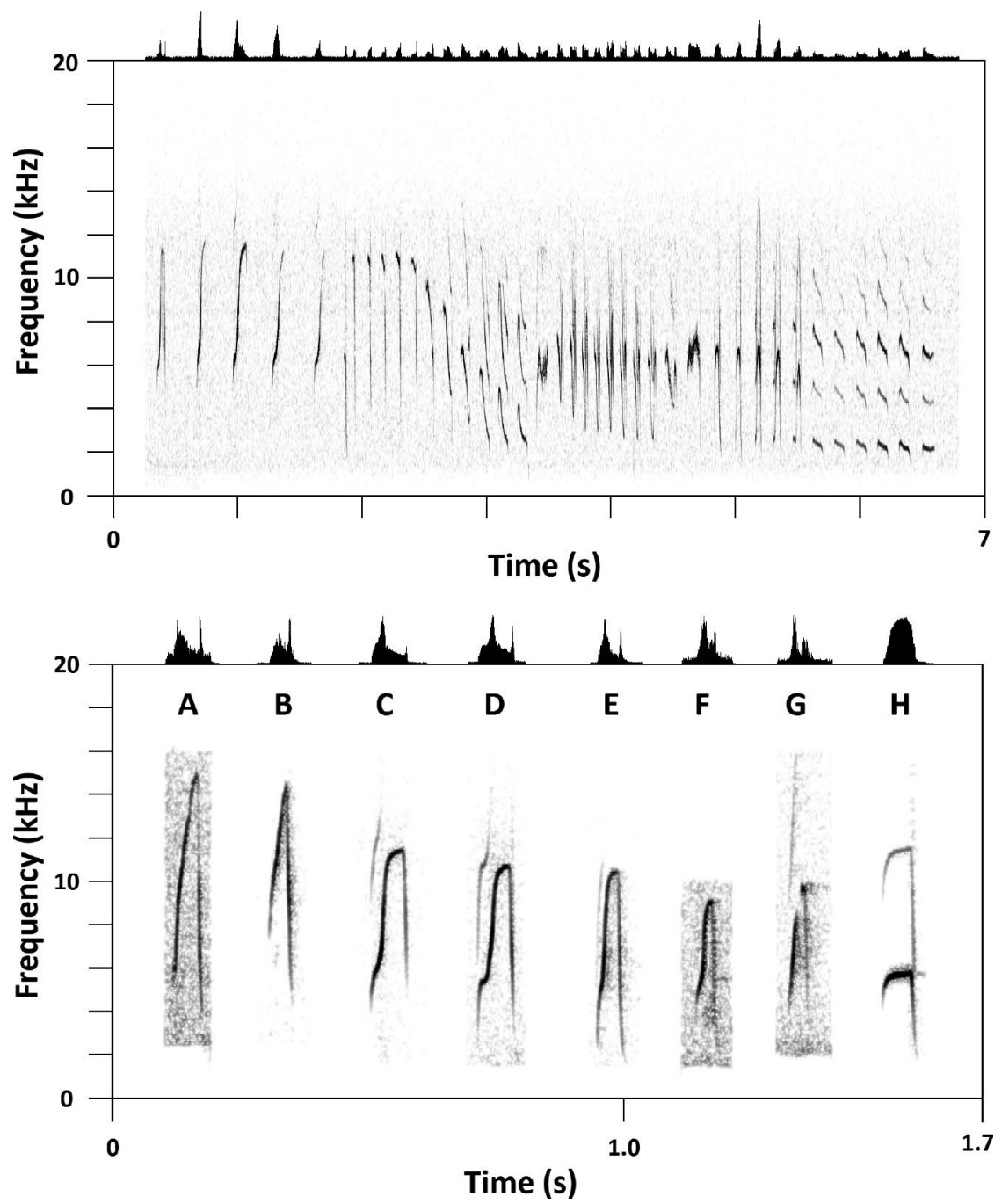

FIGURE 6. Oscillograms and sonograms of territorial song (chase call) and single-noted call of Oreotrochilus taxa. Upper panel: territorial song of male O. cyanolaemus (XC419229). Fairly similar songs are given by all other members of the genus. Lower panel: single-noted calls presumed to be homologous (except possibly G): (A) chimborazo chimborazo (OCHIMB02); (B) chimborazo jamesonii (COTOPX_0116); (C) cyanolaemus (XC419214); (D) stolzmanni (XC414298); (E) estella estella (ML33865); (F) estella bolivianus (XC95442); (G) leucopleurus (XC95441); (H) adela (XC146834). In all taxa, the call is composed of a single up-downstroke. Note the relative volume of the downstroke and the short and high-pitched peak frequency in chimborazo and jamesonii (A-B). No homologous call of melanogaster was available.

For females, the first 3 PCAs accounted for $86 \%$ of variation in the correlation matrix. The PC1 explained 39\% of the total variation, and was negatively and significantly correlated with length of rectrix $2(r=-0.81 ; t=-10.24, P$ $<0.001)$, wing length $(r=-0.74 ; t=-8.03, P<0.001)$, and tail length $(r=-0.70 ; t=-7.27, P<0.0001)$. The PC2 explained $25 \%$ of the variation, and was positively and significantly correlated with bill length $(r=0.77 ; t=8.95, P$ $<0.001$ ). Samples of $O$. cyanolaemus group closer to samples of $O$. melanogaster and O. chimborazo, and within the variation of $O$. stolzmanni. Here again, samples of $O$. leucopleurus and O. adela separate from samples of all other species, but show more dispersion than in males.
Overall, bills in O. adela are longer than in the other species (see Table S1 for raw data used in morphometrics comparisons).

Vocalizations. Judging from the limited material at hand (listed in Appendix B), the vocalizations of $O$. cyanolaemus do not differ appreciably from those of $O$. stolzmanni. Playback of song of the latter elicited strong response from 3 different individuals of $O$. cyanolaemus. A territorial song (chase call) from a male O. cyanolaemus (Figure 6) illustrates the large number of different notes found in chase calls in the genus, which makes it hard to establish homologies with small sample sizes. In all Oreotrochilus species, chase calls are given by both sexes 
and are rapid twitters of rising and falling series interspersed with rattles and a variety of different notes highly changeable in composition.

As in other Oreotrochilus species, both sexes of $O$. cyanolaemus also frequently give a short, single-noted call composed of an up-down stroke. This call differs between at least some of the taxa (Figure 6). In one individual of $O$. chimborazo chimborazo $(n=2)$ and in 6 individuals from 4 different localities of $O$. chimborazo jamesonii $(n=20)$, it has a short and high-pitched peak frequency $(13.8 \pm 1.1$ $\mathrm{kHz}$; range: $11.5-16.7 ; n=22)$ and most volume is invariably on the downstroke (Figure 6A, 6B). No similar single calls were found in any other Oreotrochilus recording. In calls from 2 individuals of $O$. cyanolaemus the peak frequency is lower $(11.1 \pm 0.6 \mathrm{kHz}$; range: $9.9-$ 11.6; $n=17)$ and of much longer duration than in $O$. chimborazo, and most volume is invariably on the upstroke. In all 3 respects, they are similar to calls of 2 individuals of $O$. stolzmanni (peak frequency: $10.3 \pm 0.3$ $\mathrm{kHz}$; range: $9.9-10.7 ; n=6$ ) and to calls of 4 individuals from 3 localities of $O$. estella $(10.0 \pm 0.7 \mathrm{kHz}$; range: $8.2-$ $11.0 ; n=43)$. Recordings from more individuals and localities are needed to prove constancy of possible difference in duration of the call between $O$. cyanolaemus and O. stolzmanni (78 $\pm 15 \mathrm{~ms}$; range: $60-122 ; n=23)$ and $O$. estella (46 $\pm 7 \mathrm{~ms}$; range: $33-56 ; n=43$ ).

Habitat and Ecology. At the type locality, Oreotrochilus cyanolaemus occurs in patches of shrubs characterized by numerous stands of Chuquiraga and dominated by shrubs in the families Asteraceae, Polygalaceae, Melastomataceae, Hypericaceae, Rubiaceae, Rosaceae, and Clethraceae (D. Fernández, personal communication). Shrub patches ranged from $0.5-1.5$ ha to a few square meters, had a dense understory, and canopy reached $3-4 \mathrm{~m}$ in height, with a few emergent shrubs up to 7-8 $\mathrm{m}$. Open grassy paramo, meadows, and cultivated/grazed paramo surrounded shrub patches. The species was also observed in stands of Chuquiraga isolated from shrubby patches, ranging from $<10 \mathrm{~m}^{2}$ to $1 \mathrm{ha}$, and reaching $2 \mathrm{~m}$ in height.

Up to 2 males and 4 females were observed in a small creek with sparse shrubs, which apparently provided shelter from windy and foggy weather. Other small creeks facing westwards were also occupied by at least one or two females, which perched low and flew up and down the creek. Also found in open, dry paramo with scarce remnant vegetation and few stands of Chuquiraga at Fierro Urcu, marginally in introduced stands of Pinus radiata at the type locality, and once in a 0.6 ha woodland patch dominated by Polylepis sp. and Gynoxys sp. at Laguna de Chinchilla. Topography of areas occupied by $O$. cyanolaemus was hilly terrain, steep hills, rocky outcrops, and creeks with gentle slopes.

Oreotrochilus cyanolaemus fed mostly by clinging sideways and upside down, but also perching next to flowers. It was observed once hovering in front of flowers (B. Vásquez et al., personal communication). Often, it perched a few seconds in the flowering shrub before visiting flowers. Main feeding plant is Chuquiraga jussieui (Asteraceae), but it was also observed feeding on the shrubs Macleania rupestris (Ericaceae) and Lleresia hypoleuca (Asteraceae). Four morphotypes of flies were found in stomach contents of collected male specimens.

Adult male and female-plumaged individuals of Oreotrochilus cyanolaemus were seen perching on lichen-laden rocks and boulders, often near ground. Also perched on exposed stumps of Puya hamata (Bromeliaceae) up to $4 \mathrm{~m}$ above ground, and in living or dead (burnt) Puya leaves a few centimeters from ground level. They regularly perched atop Chuquiraga jussieui, Macleania rupestris, Monnina sp., and other shrubs up to $5 \mathrm{~m}$ from ground, as well as on fence posts, barbwire, and in introduced pine trees up to $12 \mathrm{~m}$ high. Females were observed perching and even disputing one perch next to a small rushing stream that had abundant swarming flies, making short aerial sallies after flies.

Oreotrochilus cyanolaemus was regularly chased away by dominant Shining Sunbeam (Aglaeactis cupripennis) from nectar sources, including M. rupestris and C. jussieui. Other concurring hummingbirds at the type locality include Sparkling Violetear (Colibri coruscans), Great Sapphirewing (Pterophanes cyanoptera), Black-tailed Trainbearer (Lesbia victoriae), and Viridian Metaltail (Metallura williami), but most were less dominant and aggressive than A. cupripennis. A few antagonistic interactions were observed with $M$. williami. Male $O$. cyanolaemus apparently occupied the periphery of shrubby patches and were shy and cautious when approaching flowering stands. Females were even more cautious, approaching flowering stands and shrubby patches from nearby small creeks, and flying low above ground. Adult males chased immature males away from flowering stands, mostly of Chuquiraga jussieui, uttering high-pitched, fast, and jumbled chase calls. Males were also observed making high (20-25 m above ground), long, and direct flights from flowering stands and shrub patches, apparently heading toward other habitat patches.

During collecting trips, after evaluating the local density of both males and females, we only collected the number of specimens that we considered appropriate for a thoughtful species description. Twelve additional individuals were observed during fieldwork, including 6 adult males, 4 females, and 2 immature males in 2017 in and near Cerro de Arcos; 5 adult males and 6 females were observed in 2018 in the same area. Interestingly, 2 days after the first collecting event (at $1 \mathrm{~km} \mathrm{~W}$ of Refugio de Cerro Arcos) and $8 \mathrm{mo}$ after the second collecting event (at $3.9 \mathrm{~km}$ E of Refugio de Cerro de Arcos), we were able to observe that the territories initially occupied by the 
TABLE 2. Uncorrected pairwise genetic distances between species of Oreotrochilus. Diagonal: distances within species; upper diagonal: distances between species.

\begin{tabular}{llccccc}
\hline & \multicolumn{1}{c}{ Species } & 1 & 2 & 3 & 4 & 5 \\
\hline 1 & O. cyanolaemus & 0.0005 & 0.0010 & 0.0042 & 0.0144 & 0.0288 \\
2 & O. stolzmanni & & 0.0018 & 0.0041 & 0.0138 & 0.0141 \\
3 & O. melanogaster & & & - & 0.0054 & 0.0288 \\
4 & O. chimborazo & & & 0.0098 & 0.0371 \\
5 & O. estella & & & & -0.0288 \\
6 & O. leucopleurus & & & & 0.0393 \\
\hline
\end{tabular}

collected individuals had been occupied by other individuals of the same species and the same sex.

Distribution. Oreotrochilus cyanolaemus is only known from 5 localities in Cordillera de Chilla-Tioloma-Fierro Urcu, western Andes of southern Ecuador (Figure 2A): (1) Cerro $\operatorname{Arcos}\left(3.5662^{\circ} \mathrm{S}, 79.4580^{\circ} \mathrm{W} ; 3,648 \mathrm{~m}\right.$ a.s.l.), at the border between El Oro and Loja province; (2) base of Cerro de Arcos on the road to Celén, $3.9 \mathrm{~km}$ E of Cerro de $\operatorname{Arcos}\left(3.5577^{\circ} \mathrm{S}, 79.4217^{\circ} \mathrm{W} ; 3,374 \mathrm{~m}\right.$ a.s.l.), Loja province; (3) La Capilla, near laguna de Chinchilla $\left(3.6053^{\circ} \mathrm{S}\right.$, $79.3857^{\circ} \mathrm{W} ; 3,626 \mathrm{~m}$ a.s.l.), Loja province; (4) $7.8 \mathrm{~km} \mathrm{SW}$ of Guanazán $\left(3.5212^{\circ} \mathrm{S}, 79.5216^{\circ} \mathrm{W} ; 3,513 \mathrm{~m}\right.$ a.s.l.), El Oro province; (5) Fierro Urcu $\left(3.6993^{\circ} \mathrm{S}, 79.3544^{\circ} \mathrm{W} ; 3,618 \mathrm{~m}\right.$ a.s.l.), Loja province. Altitudinal range where observed at these localities was 3,325-3,680 $\mathrm{m}$ a.s.l. The linear distance between the most distant sites was only $27 \mathrm{~km}$.

The distributional range of $O$. cyanolaemus, as currently known, is confined to small ridges not surpassing 3,700 m a.s.l., both on east- and west-facing slopes and upper ridges of the west Andean cordillera. It is limited by the JubonesLeón river valley to the north and northeast, respectively, and by the lower Andes of the Puyango-Catamayo drainages to the south, and spans $\sim 114 \mathrm{~km}^{2}$. Its range is separated by only $40 \mathrm{~km}$ from the southern distribution end of O. chimborazo, and by more than $100 \mathrm{~km}$ from the northernmost locality of $O$. stolzmanni.

The ENM developed to predict the potential distribution of the species beyond the known occurrences was statistically significant, according to the Pearson et al. (2007) validation test $(\mathrm{D}=1 ; P<0.001)$. This analysis, however, is merely exploratory and its results must be taken with caution because of the low sample size $(n=5)$. As expected, high probability of presence was projected along the southwestern paramos, between El Oro and Loja provinces, around the occurrence localities. Beyond that region, the prediction encompasses the paramos of Cajas, marginally the paramos of Azuay-Morona-Zamora (sensu Cuesta et al. 2011), and the paramos of the western and eastern cordilleras. Areas of lower probability of occurrence extend to the Lagunillas-Piura-Podocarpus paramos (sensu Cuesta et al. 2011), to the south, and then areas of higher probability of occurrence are shown south to the North Peruvian Low (Figure 2B). No sightings of the species have been recorded in the areas shown in Figure 2C.

Evolutionary Relationships. According to the phylogenetic analysis based on the gene ND2 (Figure 3), Oreotrochilus cyanolaemus is most closely related to $O$. stolzmanni and O. melanogaster, although nodal support for this relationship was relatively low $(66 \mathrm{ML}$ bootstrap [MLboot] support/0.73 Bayesian posterior probability [Bpp]). This group of 3 species is sister to O. chimborazo, a relationship supported by both high ML bootstrap and Bayesian posterior probabilities (77 MLboot/1.00 Bpp). A phylogenetic group formed by O. estella and O. leucopleurus (65 MLboot/0.78 Bpp) is sister to all other species of Oreotrochilus; however, it is important to notice that $O$. adela, the species with the most deviating plumage, was not included in the analysis. Information for all sequences included in the analysis is available in Appendix C. Uncorrected genetic pairwise distances (Table 2) were smaller between $O$. cyanolaemus and $O$. stolzmanni (0.10\%), O. stolzmanni and O. melanogaster $(0.41 \%)$, and O. cyanolaemus and O. melanogaster (0.42\%), coherent with the grouping of these 3 species within the same clade in phylogenetic analyses. Sequences of O. cyanolaemus were most different from $O$. estella and O. leucopleurus (2.89\% in both cases); the highest distance was found between O. chimborazo and O. leucopleurus (3.93\%).

Etymology. The compound specific epithet is a Latinized Greek noun in apposition (ICZN 1999) and describes the most distinctive character of the new species: its deep to ultramarine blue (kuanos) throat patch or gorget (laimos $=$ throat).

\section{DISCUSSION}

\section{Species Validity}

Here, we recognize Oreotrochilus cyanolaemus as a new species, according to the general lineage concept of species (de Queiroz 2007). Based on several operational criteria (discussed below), we conclude that O. cyanolaemus is evolving independently from other lineages.

The new species shows unambiguous phenotypic diagnosability. Plumage characters that distinguish $O$. cyanolaemus are discrete, and both males and females 
are readily separated from all congeners. No intermediate forms between O. cyanolaemus and O. stolzmanni, the most similar species, have been recorded.

Moreover, we argue that differentiation in plumage characters may be indicative of reproductive isolation between $O$. cyanolaemus and other species. The most striking plumage trait that characterizes $O$. cyanolaemus, color of gorget, has been identified as important during sexual displays in other species of hummingbirds (e.g., Stiles 1982, Ornelas et al. 2002). Together with intensity of song and shuttle display, postures that show crown and gorget to "maximum effect" (of structural colors) have been proposed as the most critical displays as isolating mechanisms in Anna's Hummingbird (Calypte anna), "occurring as they do at close quarters immediately before copulation" (Stiles 1982). A description of reproductive behavior in O. estella is not explicit about the role of the gorget in mating displays, but mentions the fanning of tail and opening of wings in front of the female (Dorst 1962, Lagner 1973), a position that in hummingbirds is usually coupled with better exposure of the gorget. Also, in $O$. estella, observations of interactions between males visiting territorial females involve silent display of the green gorget, belly, and fanned tail (Carpenter 1976). If these behaviors are similar in displaying males of O. cyanolaemus, gorget color could be important during mate choice. Thus, assuming that signals used in mate choice are relevant in species recognition, differentiation of this character may be indicative of reproductive isolation.

Vocalizations shed little light on the subject. Oreotrochilus cyanolaemus differs markedly from both subspecies of $O$. chimborazo in both pitch and shape of the call, but no vocal difference was discerned between $O$. cyanolaemus and O. stolzmanni. Playback of song of O. stolzmanni repeatedly elicited response from $O$. cyanolaemus. Thus, vocal differences appear to evolve slower than plumage in the genus.

Other operational criteria for defining species usually include reciprocal monophyly and morphometric differentiation. However, here we argue that these criteria may be inapplicable in this case for a number of reasons. In at least 2 speciation scenarios, the condition of reciprocal monophyly is not fulfilled: when speciation occurs in the presence of gene flow (Pinho and Hey 2010, Supple et al. 2015, Kumar et al. 2017) or when speciation is recent and incomplete lineage sorting obscures the true evolutionary history of the species (Maddison and Knowles 2006, Knowles and Carstens 2007). Given the geographicecological isolation of $O$. cyanolaemus, the second scenario might apply, with the species being too young for sufficient accumulation of nucleotide synapomorphies in ND2 that could produce a pattern of reciprocal monophyly.

A time-calibrated tree based on 5 loci (McGuire et al. 2014 supplemental information) suggests that the Oreo- trochilus lineage evolved roughly 8-7 MYA, but the oldest sampled species, $O$. estella, evolved $\sim 1$ MYA, and the youngest sampled clade-formed by $O$. stolzmanni and $O$. melanogaster-is as young as $\sim 0.2 \mathrm{myr}$. According to these data, the clade that includes O. cyanolaemus is the youngest of the subfamily Lophornithini (coquettes) and is among the youngest of all hummingbirds. Thus, because of this young age, it is possible that not enough genetic variation has accumulated to be able to separate species, at least in the mitochondrial marker used in our study. As an example among hummingbirds, divergence between sister species Coeligena bonapartei and C. helianthea, which are strikingly different in ventral coloration, also happened 0.2 MYA (McGuire et al. 2014 supplemental information). In this case, trees based on 2 mitochondrial and 5 nuclear genes (Parra et al. 2009), ultra-conserved elements, and resequencing of whole mitochondrial genomes (Palacios et al. 2017) were unable to recover reciprocal monophyly. Only nuclear genome resequencing of $1,718,603$ single nucleotide polymorphisms clearly separated these 2 species into well defined, independent evolutionary lineages (Palacios et al. 2017). Thus, only use of fast-evolving, genome-wide markers may be able to show a precise sequence of splitting events between $O$. cyanolaemus, O. stolzmanni, and O. melanogaster.

On the other hand, consistent morphometric differences could result from strong natural and/or sexual selection, and thus, be useful taxonomic characters when assessing the validity of a species (see Padial et al. 2010). However, we found no indication of clear morphometric differentiation in O. cyanolaemus or even among O. melanogaster, O. stolzmanni, O. chimborazo, and O. estella (Figure 5), but a larger sample size for all species combined with more comprehensive morphometric analyzes (e.g., Cadena et al. 2018) might show significant differences. Yet, morphometric similarity in these species could be related to selective constraints imposed by high Andean habitats. Low temperatures, low oxygen levels, perched feeding of nectar, and high dependence on Chuquiraga flowers may stabilize measurements related to overall body size, and particularly wing length, rectrix width, and bill size. Thus, conservatism in morphological measurements is most likely related to ecological niche conservatism and stabilizing selection, an expected outcome among closely related and allopatric species that inhabit similar environments (Peterson et al. 1999, Kozack and Wiens 2006, Pyron et al. 2015).

Even though our small dataset limited us to obtain significant differences in call structure, molecular characters, or morphometric traits, considerations discussed above allow us to recognize Oreotrochilus cyanolaemus as a new species. The main operational criteria for delimiting this species are phenotypic diagnosability and indirect evidence of reproductive isolation from other 
species, as suggested by differences in coloration of signal function traits and geographic isolation. We think that these criteria are relevant in a group of sexually dichromatic species, where female choice could drive rapid fixation of which seem to be sexually selected characters, such as gorget and crown color (Stiles 1982, Parra 2010). Moreover, given its small range and considerable geographic isolation from $O$. stolzmanni, we hypothesize that $O$. cyanolaemus has also accumulated considerable neutral variation along its genome, but this last possibility needs to be tested using genome-wide, fastevolving markers such as single nucleotide polymorphisms.

\section{Geographic Range and Biogeography of Oreotrochilus cyanolaemus}

Both geographic distributions and ecological niche models are congruent in the geographic and ecological isolation of O. cyanolaemus. The paramos of Chilla-Tioloma-Fierro $\mathrm{Urcu}$ are isolated from the paramos of Cajas by the Jubones River valley, from the paramos of Azuay-MoronaZamora by the León River valley, except in the area south of Saraguro where it connects with Cordillera Cordoncillo (but at a lower elevation), and from the paramos of Lagunillas-Piura-Podocarpus, by the Catamayo and Malacatos river valleys (Figure $2 \mathrm{~B}$ ).

Other important factors that might explain the distribution of O. cyanolaemus and other Oreotrochilus are the soil conditions necessary for the establishment and growth of Chuquiraga jussieui, as well as other dwarfed plants. Differences in soil conditions may explain why environmental suitability (albeit low) in areas of the AzuayMorona-Zamora and Lagunillas-Piura-Podocarpus paramos is not matched by presence records of any Oreotrochilus. In fact, the only site where Chuquiraga has been found is above Jimbura, on the dry west slope of Lagunillas (Jørgensen and Ulloa Ulloa 1994), coinciding with the only occurrence of O. stolzmanni in Ecuador.

Also, although environmental suitability is high in the paramos of Cajas, this well-studied region is known to be inhabited only by O. chimborazo (Astudillo et al. 2015). Besides the lack of records of $O$. cyanolaemus, the ecological similarities with $O$. chimborazo suggest that $O$. cyanolaemus has not reached that region or was not able to establish a breeding population there. Geographic isolation, poor environmental unsuitability, and, probably, soil conditions, seem to preclude the Lagunillas-PiuraPodocarpus paramos from serving as stepping stones between $O$. cyanolaemus and O. stolzmanni, at least in their present configuration. Interestingly, Zimmer (1951) predicted that "there are few places between the range of O. chimborazo and O. stolzmanni where a population [of Oreotrochilus] might exist..."; it seems that the only such place is the region inhabited by O. cyanolaemus.

\section{Evolutionary Relationships and Speciation of Oreotrochilus cyanolaemus}

Based on the combination of evidence provided by the phylogenetic tree, pairwise genetic distances, overall plumage and vocal similarities, and geographic vicinity, we hypothesize that $O$. stolzmanni is the sister species of O. cyanolaemus. These considerations provide further support for the ranking of O. stolzmanni as full species, as proposed by Fjeldså and Boesman (2017). Genetic distances (ND2) in the genus Oreotrochilus are likely not reflected in plumage differences, as indicated by plumage similarities but large genetic distance between $O$. stolzmanni and O. estella, or by the notably different plumages but short genetic distance between $O$. cyanolaemus and $O$. melanogaster.

On the other hand, the diagnostic characters of $O$. cyanolaemus, its distribution and its allopatry with respect to O. stolzmanni, allow for preliminary hypotheses for its evolutionary origin. Given the small range of O. cyanolaemus compared to that of O. stolzmanni, it is possible that its separation from an ancestral population occurred as a peripheral isolate. Then, based on the ubiquity of whole green gorgets in Oreotrochilus (except for O. chimborazo and $O$. cyanolaemus), and assuming a scenario of sexual selection for gorget coloration, mutations that caused color change in this character-coupled with strong female preference for the new color-may have easily become widespread in the population of pre-O. cyanolaemus. Finally, taking its restricted distribution as a proxy for small population size, such mutations could have fixed in relatively short evolutionary time, causing speciation. Such a scenario would be consistent with current understanding of incipient speciation events that involve both allopatry and plumage changes (e.g., Uy et al. 2009). A simpler scenario of speciation caused by sampling effects and genetic drift after peripheral isolation is also plausible. Determining whether northern dispersal of the ancestral population from Jimbura to the Chilla-Tioloma-Fierro Urcu mountains occurred during glacial periods, when most paramo areas were connected (see Hooghiemstra and Van der Hammen 2004), and whether the LagunillasPiura-Podocarpus paramos may have served as stepping stones during those times, deserves further investigation.

\section{Conservation Status}

Oreotrochilus cyanolaemus has a highly restricted distribution, with an optimistic estimate of its range barely surpassing $100 \mathrm{~km}^{2}$. Within its small range, it is seemingly confined to creeks with remaining stands of Chuquiraga jussieui and other bushes. Burning of paramo grasses is a major threat in the area, as indicated by the large expanses of burnt vegetation witnessed by the authors across its range. Paramos at Cerro de Arcos and vicinities are or have been heavily grazed by cattle and horses, and areas with 
gentle slopes are primarily transformed into crops and pastureland. Pine plantations occupy large areas at currently known localities, and progressively dominate the landscape over disturbed grassy paramo and shrub patches. Furthermore, a large proportion of its known range is currently under gold mining concessions (Agencia de Regulación y Control Minero 2017).

The fate of $O$. cyanolaemus is likely critical, with no land protection and no conservation measures known to us. Even though population numbers are not known, we suggest a very small population (at best, 250-750 individuals, but possibly below 500 individuals) inferred from numbers of male birds and territorial females observed in the field, and limited suitable feeding and nesting habitat along a small range (Pearson 1953, Carpenter 1976). Nonetheless, this preliminary estimate needs to be reassessed with a thorough population census. Our observation that territories of collected individuals were readily or eventually occupied by other individuals of the same species has 2 important implications: (1) collecting for description purposes was unlikely to affect the effective population size of these populations; and (2) it suggests that, in this species, the major limitation for population growth is territory availability (see Newton 1992).

Following IUCN criteria for conservation status assessments (UICN 2012), we evaluate O. cyanolaemus as Critically Endangered (CR) given that its actual extent of occurrence is likely below the $100 \mathrm{~km}^{2}$ thresholdconsidering its absence from apparently suitable localities within its small distribution range-and is known from a single location where area of occupancy, habitat quality, and number of mature individuals is possibly declining (criterion B1a,b [ii,iii,v]; see UICN 2012). IUCN defines a location as a geographically or ecologically distinct area in which a single threatening event can rapidly affect all individuals of the taxon present; it may include part of one or many subpopulations as is likely the case with $O$. cyanolaemus. No conservation measures have been taken to date, but a nature tourism initiative is currently underway at Cerro de Arcos, managed by the local community of Sabadel, and a conservation action plan is currently being designed.

\section{ACKNOWLEDGMENTS}

Thanks to Paul Greenfield for the superb illustration that accompanies this paper; Nicolás Peñafiel for performing molecular procedures; Mark Adams (NHM, Tring), Gerald Mayr (SNM, Frankfurt), César Garzón (MECN, Quito), and Gabriela Toscano and Santiago Burneo (QCAZ, Quito) for granting access to collections under their care. Doug Weschler provided photos of specimens held at the ANSP. Boris Tinoco, Bernarda Vásquez, and Patricio Picón (Uni- versidad del Azuay) contributed with behavioral information. Carlos A. Rodríguez-Saltos contributed with unpublished locality observations and together with Fernanda Duque, provided access to unpublished sound recordings. Judith Denkinger and Ana C. Torres helped translating German and French literature. Javier Yánez (MECN, Quito) identified stomach contents of Cerro de Arcos specimens and Diana Fernández (Herbario Nacional, Inabio, Quito), Zhofre Aguirre and Wilson Quishpe (Herbario Reinaldo Espinosa, Universidad Nacional de Loja) helped with plant identification and habitat information. Thanks to Guy Kirwan, Daniel Lebbin, Manuel Sánchez-Nivicela, Matthew Medhler (Macaulay Library), Arnau Bonan (Internet Bird Collection), Christopher Witt, and Wendy Willis for various contributions, and to Juan M. Guayasamin, Garth Spellman, and 2 anonymous reviewers for their insightful revision of the manuscript. Thanks to Fundación EcoCiencia for supporting planning of conservation actions. Our sincere thanks to Bernardino Loja Arévalo, Tania Romero, and Franco Teruzzi for hospitality and further assistance at Cerro de Arcos.

Funding statement: This work was partially financed by grants from Universidad Tecnológica Indoamérica and Universidad San Francisco de Quito (HUBI: 5447) to E. Bonaccorso.

Ethics statement: Collection of specimens and genetic analyses were authorized under Contrato de Acceso a Recursos Genéticos MAE-DNB-CM-2015-0017, between Universidad Tecnológica Indoamérica and Ministerio del Ambiente, Ecuador.

Authors contribution: F.S.M. made initial discovery; F.S.M., J.N., N.K., and J.F.F. collected specimens and field data; F.S.M. procured partial funding, and botanical and stomach content identifications; E.B. and J.F.F. supervised research; E.B., J.F.F., and N.K. developed or designed methods; E.B., J.F.F., J.N., and N.K. analyzed the data; E.B. and J.F.F. wrote the paper; J.N. and N.K. substantially edited the paper.

Data deposits: All genetic data are deposited in GenBank. Photographs and audio recordings were deposited in the Internet Bird Collection, Xeno-Canto, and Macaulay Library. Nomenclature review: The nomenclature in this paper has been reviewed by the Working Group on Avian Nomenclature of the International Ornithologists' Union.

Oreotrochilus cyanolaemus was registered on ZooBank and it received the following LSID: urn:lsid:zoobank.org:pub:4944DAAD-1338-44EE-A991-AB3F97BB3D9E

\section{LITERATURE CITED}

Agencia de Regulación y Control Minero (2017). Catastro minero. Ministerio de Minas, Quito, Ecuador. http://geo. controlminero.gob.ec:1026/geo_visor/

Astudillo, P. X, B. A. Tinoco, and D. C. Siddons (2015). The avifauna of Cajas National Park and Mazán Reserve, southern Ecuador, with notes on new records. Cotinga 37:2-12.

Cadena, C. D., F. Zapata, and I. Jiménez (2018). Issues and perspectives in species delimitation using phenotypic data: Atlantean evolution in Darwin's finches. Systematic Biology 67:181-194. 
Carpenter, F. L. (1974). Torpor in an Andean hummingbird: Its ecological significance. Science 183:545-547.

Carpenter, F. L. (1976). Ecology and evolution of an Andean hummingbird (Oreotrochilus estella). University of California Publications in Zoology 106:1-74.

Clement, M. D., K. Posada, and A. Crandall (2000). TCS: A computer program to estimate gene genealogies. Molecular Ecology 9:1657-1659.

Clements, J. F., T. S. Schulenberg, M. J. Iliff, D. Roberson, T. A. Fredericks, B. L. Sullivan, and C. L. Wood (2017). The eBird/ Clements checklist of birds of the world: v2016. Cornell University, Ithaca, NY, USA. http://www.birds.cornell.edu/ clementschecklist/download/

Cuesta, F., S. Salgado, B. De Bièvre, and K. Beltrán (2011). Unidades Fisiográficas de los Páramos Andinos. CONDESAN, Proyecto Páramo Andino, Quito, Ecuador.

de Queiroz, K. (2007). Species concepts and species delimitation. Systematic Biology 56:879-886.

Dorst, J. (1962). Nouvelles recherches biologiques sur les trochilidés des hautes Andes péruviennes (Oreotrochilus stella). L'Oiseau et Revue Français d'Ornithologie 32:95-126.

Fjeldså, J., and P. Boesman (2017). Green-headed Hillstar (Oreotrochilus stolzmanni). In Handbook of the Birds of the World Alive (J. del Hoyo, A. Elliott, J. Sargatal, D. A. Christie, and E. de Juana, Editors). Lynx Edicions, Barcelona, Spain. http://www.hbw.com/node/55553

Fjeldså, J., and N. Krabbe (1990). Birds of the High Andes. Zoological Museum, University of Copenhagen, Copenhagen, Denmark.

French, N. R., and R. W. Hodges (1959). Torpidity in cave-roosting hummingbirds. The Condor 61:223-228.

Gould, J. (1847). Drafts for an arrangement of the Trochilidae, with description of some new species. Proceedings of the Zoological Society of London 15:9.

Hijmans, R. J., S. E. Cameron, J. L. Parra, P. G. Jones, and A. Jarvis (2005). Very high resolution interpolated climate surfaces for global land areas. International Journal of Climatology 25: 1965-1978.

Hooghiemstra, H., and T. van der Hammen (2004). Quaternary Ice-Age dynamics in the Colombian Andes: Developing an understanding of our legacy. Philosophical Transactions of the Royal Society of London B 359:173-181.

[ICZN] International Commission on Zoological Nomenclature (1999). International Code of Zoological Nomenclature, 4th edition. International Trust for Zoological Nomenclature, London, UK.

Jørgensen, P. M., and C. Ulloa Ulloa (1994). Seed Plants of the High Andes of Ecuador - A Checklist. AAU Reports 34, Aarhus University Press, Aarhus, Denmark. http://www.aubot.dk/ show_entry.php?CatalogNumber=P.M.Jorgensen92236\&

Knowles, L. L., and B. C. Carstens (2007). Species without monophyletic gene trees. Systematic Biology 56:887-895.

Kozack, K. H., and J. J. Wiens (2006). Does niche conservatism promote speciation? A case study in North American salamanders. Evolution 60:2604-2621.

Kumar, V., F. Lammers, T. Bidon, M. Pfenninger, L. Kolter, M. A. Nilsson, and A. Janke (2017). The evolutionary history of bears is characterized by gene flow across species. Scientific Reports 7:46487.
Lagner, S. (1973). Zur Biologie des Hochlandkolibris Oreotrochilus estella in den Anden Boliviens. Bonner Zoologische Beiträge 24:24-47.

Lanfear, R., P. B. Frandsen, A. M. Wright, T. Senfeld, and B. Calcott (2016). PartitionFinder 2: New methods for selecting partitioned models of evolution for molecular and morphological phylogenetic analyses. Molecular Biology and Evolution 34: 772-773.

Larkin, M. A., G. Blackshields, N. P. Brown, R. Chenna, P. A. McGettigan, H. McWilliam, F. Valentin, I. M. Wallace, A. Wilm, R. López, J. D. Thompson, et al. (2007). Clustal W and Clustal X version 2.0. Bioinformatics 23:2947-2948.

Maddison, W. P., and L. L. Knowles (2006). Inferring phylogeny despite incomplete lineage sorting. Systematic Biology 55: 21-30.

Maddison, W. P., and D. R. Maddison (2017). Mesquite: A modular system for evolutionary analysis. Version 3.2. http:// mesquiteproject.org

Mc Guire, J. A., C. C. Witt, J. V. Remsen, A. Corl, D. L. Rabosky, D. L. Altshuler, and R. Dudley (2014). Molecular phylogenetics and the diversification of hummingbirds. Current Biology 24:1-7.

McGuire, J. A., C. C. Witt, J. V. Remsen, R. Dudley, and D. L. Altshuler (2009). A high-level taxonomy for hummingbirds. Journal of Ornithology 150:155-165.

McMullan, M. (2016). Field Guide to the Hummingbirds. Ratty Ediciones, Quito, Ecuador.

Newton, I. (1992). Experiments on the limitation of bird numbers by territorial behaviour. Biological Reviews 67:129-173.

Ornelas, J. F., C. González, and J. Uribe (2002). Complex vocalizations and aerial displays of the Amethyst-throated Hummingbird (Lampornis amethystinus). The Auk 119:11411149.

Ortiz-Crespo, F., and R. Bleiweiss (1982). The northern limit of the hummingbird genus Oreotrochilus in South America. The Auk 99:376-378.

Padial, J. M., A. Miralles, I. De la Riva, and M. Vences (2010). The integrative future of taxonomy. Frontiers in Zoology 7:16.

Palacios, C., S. García, J. L. Parra, A. M. Cuervo, F. G. Stiles, J. McCormack, L. Campagna, and C. D. Cadena (2017). Shallow evolutionary divergence between two Andean hummingbirds. Evolution 2017, 25 June 2017. Portland, OR, USA. https://www. youtube.com/watch?v=VPOeTgITgPk\&feature=youtu.be

Parra, J. L. (2010). Color evolution in the hummingbird genus Coeligena. Evolution 64:324-335.

Parra, J. L., J. V. Remsen, M. Álvarez-Rebolledo, and J. McGuire (2009). Molecular phylogenetics of the hummingbird genus Coeligena. Molecular Phylogenetics and Evolution 53:425434

Pearson, O. P. (1953). Use of caves by hummingbirds and other species at high altitudes in Peru. The Condor 55:17-20.

Pearson, R. G., C. J. Raxworthy, M. Nakamura, and A. T. Peterson (2007). Predicting species distributions from small numbers of occurrence records: A test case using cryptic geckos in Madagascar. Journal of Biogeography 34:102-117.

Peters, J. L. (1945). Check-list of Birds of the World 5. (Trochili, Coliiformes, Trogoniformes, Coraciiformes). Harvard University Press, Cambridge, MA, USA.

Peterson, A. T., J. Soberón, and V. Sánchez-Cordero (1999). Conservatism of ecological niches in evolutionary time. Science 285:1265-1267. 
Phillips, S. J., R. P. Anderson, and R. E. Schapire (2006). Maximum entropy modeling of species geographic distributions. Ecological Modeling 190:231-259.

Pinho, C., and J. Hey (2010). Divergence with gene flow: Models and data. Annual Review of Ecology, Evolution and Systematics 41:215-230.

Pyron, R. A., G. C. Costa, M. A. Patten, and F. T. Burbrink (2015). Phylogenetic niche conservatism and the evolutionary basis of ecological speciation. Biological Reviews 90:1248-1262.

Remsen, J. V., J. I. Areta, C. D. Cadena, A. Jaramillo, M. Nores, J. F. Pacheco, J. Pérez-Emán, M. B. Robbins, F. G. Stiles, D. F. Stotz, and K. J. Zimmer (2018). A classification of the bird species of South America. American Ornithologists' Union, Washington, DC, USA. http://www.museum.Isu.edu/ Remsen/ SACCBaseline.htm

Ridgely, R. S., and P. J. Greenfield (2001). The Birds of Ecuador: Status, Distribution and Taxonomy. Cornell University Press, Ithaca, NY, USA.

Ridgway, R. (1912). Color standards and color nomenclature. Published by the author, Washington, DC, USA.

Rodríguez-Saltos, C. A., and E. Bonaccorso (2016). Understanding the evolutionary history of a high Andean endemic: The Ecuadorian Hillstar (Oreotrochilus chimborazo). Neotropical Biodiversity 2:37-50.

Ronquist, F., and J. P. Huelsenbeck (2003). MrBayes 3: Bayesian phylogenetic inference under mixed models. Bioinformatics 19:1572-1574.

Schuchmann, K. L., and A. Bonan (2017). Hummingbirds (Trochilidae). In Handbook of the Birds of the World Alive (J. del Hoyo, A. Elliott, J. Sargatal, D. A. Christie, and E. de Juana, Editors). Lynx Edicions, Barcelona, Spain. http://www. hbw.com/node/52268

Schulenberg, T. S., D. F. Stotz, D. F. Lane, J. P. O'Neill, and T. A. Parker (2007). Birds of Peru. Princeton University Press, Princeton, NJ, USA.

Simpson, G. G. (1951). The species concept. Evolution 5:285-298.

StatSoft Inc. 2007. STATISTICA for Windows. StatSoft Inc. Tulsa, OK, USA.

Stiles, F. G. (1982) Aggressive and courtship displays of the male Anna's Hummingbird. The Condor 84:208-225.

Supple, M. A., R. Papa, H. M. Hines, W. O. McMillan, and B. A. Counterman (2015). Divergence with gene flow across a speciation continuum of Heliconius butterflies. BMC Evolutionary Biology 15:204.

Swofford, D. L. (2009). Phylogenetic analysis using parsimony (*and other methods) Ver. 4.0a109. Sinauer Associates, Sunderland, MA, USA.

[UICN] Unión Internacional para la Conservación de la Naturaleza (2012). Categorías y criterios de la lista roja de la UICN: Versión 3.1. Segunda edición. Gland, Suiza and Cambridge, UK.

Uy, J. A., R. G. Moyle, C. E. Filardi, and Z. A. Cheviron (2009) Difference in plumage color used in species recognition between incipient species is linked to a single amino acid substitution in the melanocortin-1 receptor. American Naturalist 174:244-254.

Weinstein, B. J. (2015). MotionMeerkat: Integrating motion video detection and ecological monitoring. Methods in Ecology and Evolution 6:357-362.

Wiley, E. O. (1978). The evolutionary species concept reconsidered. Systematic Zoology 27:17-26.
Zimmer, J. T. (1951). Studies of Peruvian birds. No. LX. The genera Heliodoxa, Phlogophilus, Urosticte, Polyplancta, Adelomyia, Coeligena, Ensifera, Oreotrochilus, and Topaza. American Museum Novitates 1513:1-45.

Zwickl, D. J. (2006). Genetic algorithm approaches for the phylogenetic analysis of large biological sequence datasets under maximum likelihood criterion. Ph.D. dissertation, University of Texas, Austin, TX, USA.

\section{APPENDIX A. Specimens examined (MECN $=$ Museo Ecuatoriano de Ciencias Naturales, Quito; NHM = Natural History Museum, Tring; QCAZ = Museo de Zoología, Pontificia Universidad Católica del Ecuador, Quito; SNM = Senckenberg Natural History Museum, Frankfurt).}

Oreotrochilus chimborazo chimborazo: MECN 1 adult male, 1 immature male (6128, 6585); NHM 14 adult males, 5 immature males, 9 females (1938.12.20.210, 97.11.12.88, 1953.68.248, 1969.37.70, 87.3.22.363, 87.3.22.364, 87.3.22.362, 1969.37.71, 57.5.3.69, 72.5.3.69, 72.5.28.1, 1938.12.20, 1938.12.20.211, 87.3.22.363, 1902.3.13.2001, 1969.37.72, 75.5.28.3, 97.11.12.87, 87.3.14.70, 10 unnumbered); QCAZ 4 adult males, 3 immature males, 4 females (3782, 3783, 3784, 3785, 3791, 4150, 4156, 4157, 4166, 4168, 4178) (Ecuador).

Oreotrochilus chimborazo jamesonii: MECN 5 adult males, 2 immature males, 1 female, 3 undetermined (1071, 1072, 1074, 1075, 1076, 6584, 8664, 8651, 8673, 8674, 8676); NHM 19 adult males, 4 immature males, 10 females (1940.12.5.47, 1913.3.20.956, 1953.68.250, 97.11.12.89, 87.3.22.357, 1938.12.20.212, 1925.12.24.65, 1969.38.21, 1969.38.21, 1969.51.20, 72.5.28.57, 1969.51.23, 1925.12.24.67, 1938.12.20.213, 1925.12.24.66, 1953.68.249, 97.11.12.90, 1902.3.13.2003, 1913.3.20.954, 94.2.15.51, 17.3.22.358, 87.3.22.356, 12 unnumbered); QCAZ 3 adult males, 10 immature males, 6 females $(022,606,751,3782,3789$, 3790, 4054, 4126, 4148, 4152, 4153, 4160, 4161, 4169, 4175, 4177, 4181, 4183, 4184 (Ecuador).

Oreotrochilus stolzmanni: MECN 1 immature male, 1 female (6458, 6583); NHM 2 adult males, 1 immature male, 2 females (1912.7.1, 1912.7.1.58, 1902.3.13.2004, 1912.7.1.58, 1912.7.1.59); QCAZ 1 immature male, 2 females (3868, 3901, 4192); SNM 7 adult males, 1 immature male, 3 females (75562, 75563, 75564, 75565, 75566, 75567, 75568, 75569, 75570, 75571, 75572) (Ecuador, Peru).

Oreotrochilus cyanolaemus: MECN 4 adult males, 3 females $(9614,9615,9616,9617,9618,9619,9620)$ (Ecuador).

Oreotrochilus melanogaster: NHM 7 adult males, 6 females (87.3.14.79, 1946.49.404, 1946.49.400, 1946.49.403, 

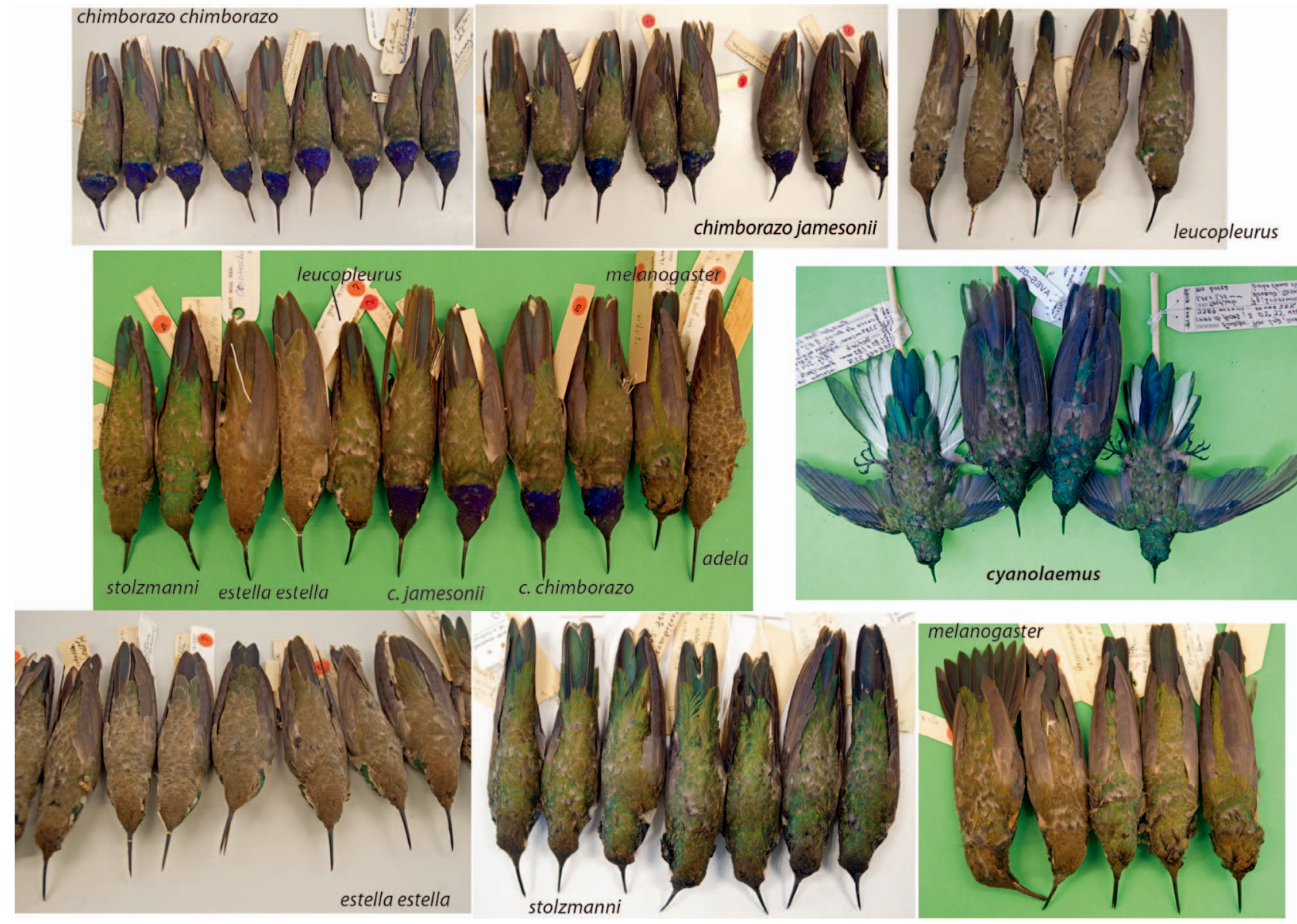

APPENDIX FIGURE 7. Dorsal view of males of 7 Oreotrochilus taxa photographed at MECN, NMH, and SNM. Only missing taxon is $O$. estella bolivianus, for which museum material is scarce. Upper row, left to right: 0 . chimborazo chimborazo NHM 87.3.22.364, NHM 87.3.22.363, unnumbered, unnumbered, unnumbered, NHM 97.11.12.88, NHM 87.3.22.362, NHM 1953.68.248, NHM 1969.37.70; O. chimborazo jamesonii NHM 87.3.22.356, unnumbered, NHM 1969.51.20, unnumbered, NHM 94.2.15.51, NHM 87.3.22.357, NHM 17.3.22.358, unnumbered; O. leucopleurus NHM 87.3.14.78, NHM 87.3.22.369, NHM 87.3.22.374, NHM 1902.3.13.2006, NHM 99.1.20.72. Middle row, left to right: O. stolzmanni NHM 1912.7.1.58, NHM 1912.7.1; O. estella estella unnumbered, NHM 1902.3.13.1999; O. leucopleurus NHM 87.3.14.78; O. chimborazo jamesonii NHM 87.3.22.356, NHM 87.3.22.363; O. chimborazo chimborazo unnumbered, NHM 57.5.3.69; O. melanogaster NHM 1946.49.405; O. adela NHM 1902.3.13.2010; O. cyanolaemus MECN 9620, MECN 9615, MECN 9614, MECN 9619. Lower row, left to right: O. estella estella unnumbered, NHM 1902.3.13.2000, NHM 1902.3.13.1999, unnumbered, unnumbered, NHM 87.3.22.367, unnumbered; O. stolzmanni SNM 75562, SNM 75563, SNM 75565, SNM 75564, SNM 75568, SNM 75566, SNM 75567; O. melanogaster NHM 87.3.22.376, NHM 87.3.14.79, NHM 1946.49.400, NHM 1946.49.403, NHM 1946.49.404.

87.3.22.376, 1946.49.399, 1946.49.401, 1946.49.398, 1946.49.405, 1948.6.5, 1948.6.6, 2 unnumbered); SNM 1 female (87278) (Peru).

Oreotrochilus estella estella: NHM 14 adult males, 5 females (87.3.22.365, 1902.3.13.2000, 1902.3.13.1999, 87.3.22.367, 87.3.2.366, 1902.3.13.1998, 192.3.13.1995, 12 unnumbered); SNM 14 adult males, 2 immature males, 11 females $(75670,75671,75811,75812,75813$, $75814,75815,75816,75817,87279,87280,87181$, $87282,87283,87284,87285,87286,87287,87290$, 87291, 87292, 87293, 87294, 87295, 87296, 87297, 87298) (Peru, Bolivia, Chile).

Oreotrochilus estella bolivianus?: SNM 1 adult male, 1 immature male $(87288,87289)$ (Bolivia).
Oreotrochilus leucopleurus: NMH 10 adult males, 3 immature males, 11 females $(87.3 .22 .369,92.2 .10 .642$, 87.3.14.78, 99.1.20.72, 87.3.22.374, 87.3.14.78, 1902.3.13.2006, 92.2.10.646, 87.3.14.77, 92.2.10.643, 87.3.22.372, 92.2.10.644, 99.1.20.41, 65.8.1551, 1902.3.13.2005, 43.7.21.46, 87.3.22.375, 87.3.14.75, 99.1.27.147, 87.3.22.371, 4 unnumbered); SNM 6 adult males, 3 immature males, 4 females (75818, 75819, 75820, 75821, 75823, 87300, 87302, 87303, 87304, 87305, 87306, 87307, 87308) (Chile, Argentina).

Oreotrochilus adela: NHM 6 adult males, 2 immature males, 7 females (87.3.22.377, 1902.3.13.2008, 1902.3.13.2010, 1902.3.13.2009, 1902.3.13.2011, 87.3.22.378, 89.3.14.80, 8 unnumbered) (Bolivia). 

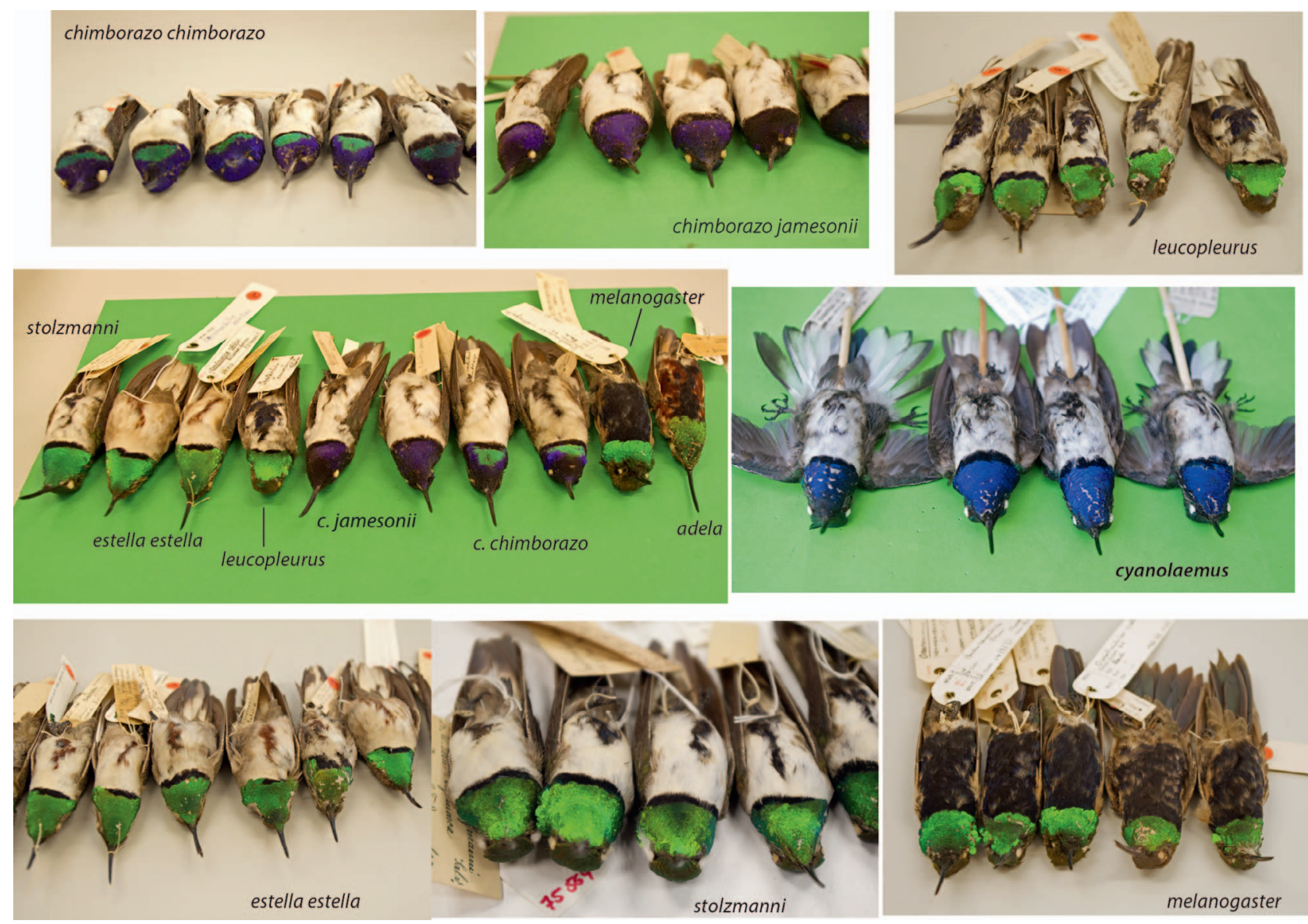

APPENDIX FIGURE 8. Ventral view of males of 7 Oreotrochilus taxa photographed at MECN, NMH, and SNM. Upper row, left to right: O. chimborazo chimborazo NHM 87.3.22.364, unnumbered, NHM 87.3.22.363, unnumbered, unnumbered, NHM 97.11.12.88; 0 . chimborazo jamesonii NHM 87.3.22.356, unnumbered, NHM 17.3.22.358, unnumbered; O. leucopleurus NHM 87.3.14.78, NHM 87.3.22.369, NHM 87.3.22.374, NHM 1902.3.13.2006, NHM 99.1.20.72. Middle row, left to right: O. stolzmanni NHM 1912.7.1; O. estella estella unnumbered, NHM 1902.3.13.1999; O. leucopleurus NHM 87.3.14.78; O. chimborazo jamesonii NHM 87.3.22.356, NHM 87.3.22.363; O. chimborazo chimborazo unnumbered, NHM 57.5.3.69; O. melanogaster NHM 1946.49.405; O. adela NHM 1902.3.13.2010. O. cyanolaemus MECN 9620, MECN 9615, MECN 9614, MECN 9619. Lower row, left to right: O. estella NHM 1902.3.13.2000, NHM 1902.3.13.1999, unnumbered, unnumbered, NHM 87.3.22.367, unnumbered; O. stolzmanni SNM 75562, SNM 75563, SNM 75565, SNM 75564; O. melanogaster NHM 1946.49.404, NHM 1946.49.400, NHM 1946.49.403, NHM 87.3.22.376, NHM 87.3.14.79.

\section{APPENDIX B. Sound recordings examined ( $M L=$ Macaulay Library, XC = Xeno Canto).}

Oreotrochilus chimborazo chimborazo (2): unpublished recordings by $\mathrm{F}$. Duque and $\mathrm{C}$. Rodríguez ( CHIMRS_0130; song), ( O C H I M B02_20151223_113800_Occ_contact01; call).

Oreotrochilus chimborazo jamesonii (10): XC260498 (feeding call), 257830 (song, call), 72706 (call imm. m), 72705 (call $\mathrm{m}$ ), 72704 (song $2 \mathrm{~mm}$ ), unpublished recording by F. Duque and C. Rodríguez (COTOPX_0116; song), (COTOPX_0116_contact4; call), (COTOPX_0123_contact1; call), (RUCPIC_0101_contact6; call), (APAGUI_0074_contact1; call).
Oreotrochilus cyanolaemus (7): XC419214/ML104900761 (call m), XC419247 (song, call $2 \mathrm{~mm}$ ), XC419237/ ML104901351 (song f), XC419234/ML104901281 (song m), XC419229/ML104900971 (song m), XC419240/ ML104901391 (wing hum m), XC419224/ ML104900901 (wing hum m).

Oreotrochilus stolzmanni (3): XC36394 (song, call $2 \mathrm{~mm}$ ), 414298 (call f), 414299 (song f).

Oreotrochilus melanogaster (5): XC41148 (song), 190606 (song), 190605 (song), 190604 (song), ML31743991 (song). Oreotrochilus estella estella (4): ML33865 (call), XC90530 (song), 59991 (call f), 59990 (call).

Oreotrochilus estella estella/bolivianus (2): XC2507 (song), 263265 (song f). 
chimborazo chimborazo

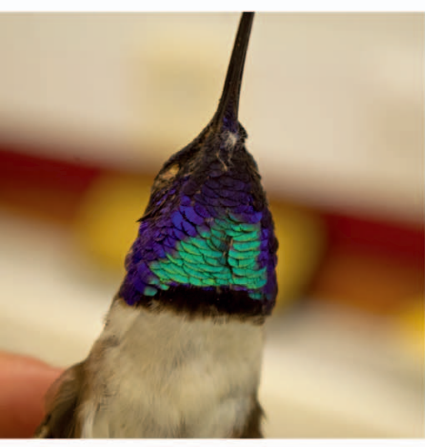

estella estella

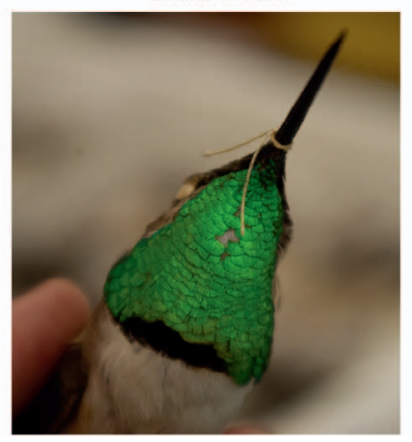

chimborazo jamesonii

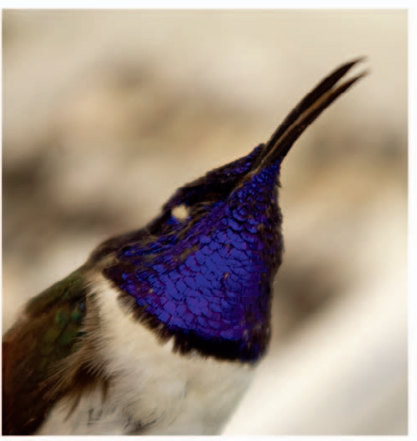

leucopleurus

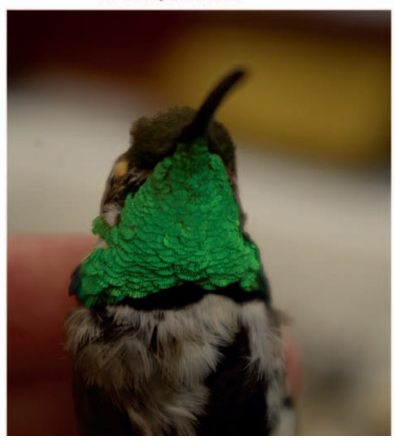

cyanolaemus

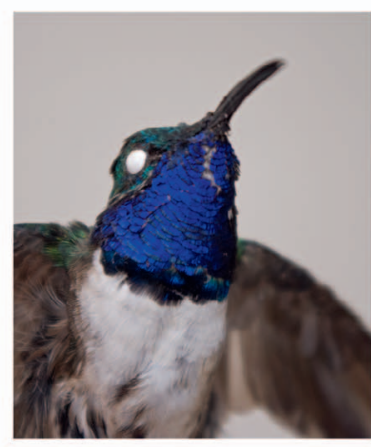

melanogaster

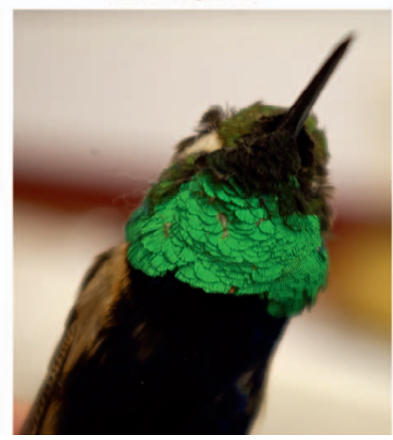

stolzmanni

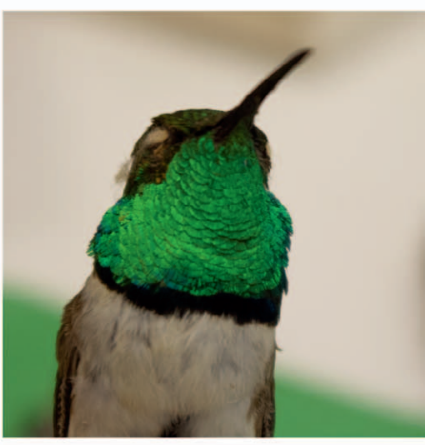

adela

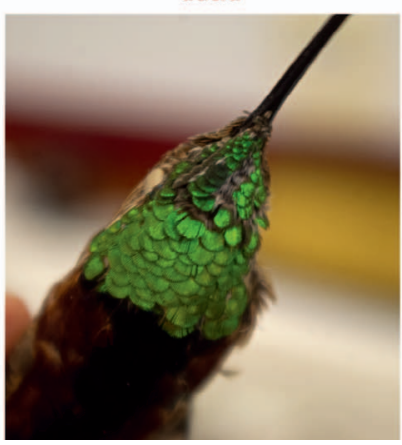

APPENDIX FIGURE 9. Details of throat patches of males of 7 Oreotrochilus taxa photographed at MECN, NMH, and SNM. Upper row, left to right: O. chimborazo chimborazo unnumbered, O. chimborazo jamesonii NHM 87.3.22.363, O. cyanolaemus MECN 9619, O. stolzmanni SNM 75567. Lower row, left to right: O. estella estella NHM 1902.3.13.1999, O. leucopleurus NHM 87.3.14.78, O. melanogaster NHM 1946.49.405, O. adela NHM 1902.3.13.2010.

\section{Oreotrochilus estella bolivianus (2): XC95443 (call f),} 95442 (call same f).

Oreotrochilus leucopleurus (5): ML204411 (chirping call), 167935 (wing noise), XC38816 (call by captive bird), 15711 (song), 95441 (call m).
Oreotrochilus adela (11): ML224855 (call), XC146834 (call $\mathrm{m}$ ), 146833 (song, call $2 \mathrm{~mm}$ one the same as 146834), 15313 (song), 4530 (buzzy call), 155971 (call), 95438 (song f), 95440 (song f, same), 95437 (song), 95436 (call), 52894 (call). 


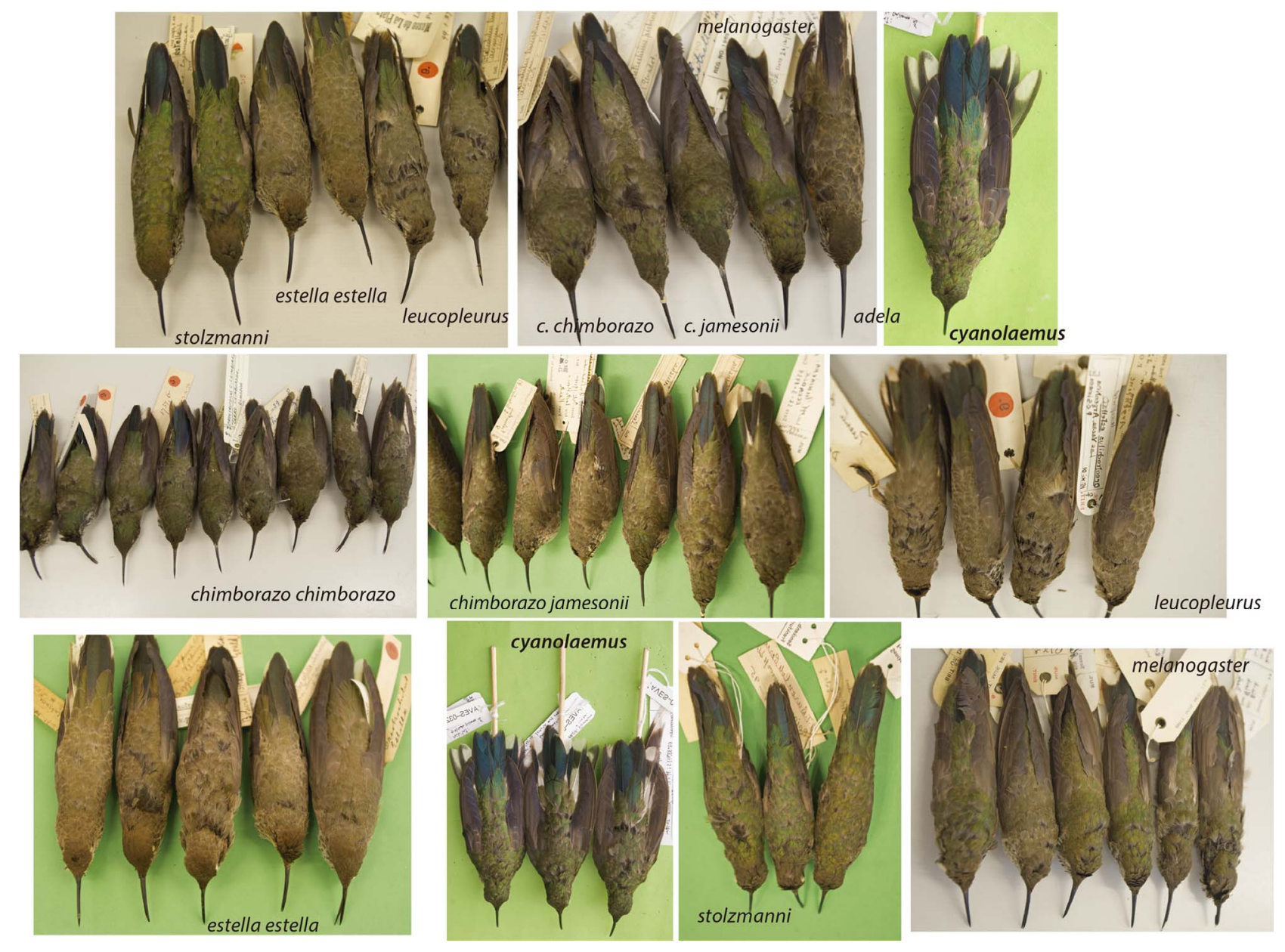

APPENDIX FIGURE 10. Dorsal view of females of 7 Oreotrochilus taxa photographed at MECN, NMH, and SNM. Upper row, left to right: O. chimborazo chimborazo NHM 1902.3.13.2001, unnumbered, NHM 87.3.14.70, unnumbered, NHM 1969.37.72, NHM 97.11.12.87, unnumbered, NHM 87.3.22.363, NHM 72.5.28.3; O. chimborazo jamesonii NHM 97.11.12.90, NHM 1925.12.24.66, unnumbered, unnumbered, unnumbered, NHM 1938.12.20.213; O. leucopleurus NHM 99.1.20.41, NHM 43.7.21.46, NHM 99.1.27.147, NHM 1902.3.13.2005. Middle row, left to right: O. stolzmanni NHM 1902.3.13.2004, NHM 1912.7.1.58; O. estella NHM 87.3.2.366, NHM 1902.3.13.1999; O. leucopleurus NHM 99.1.27.147, unnumbered; O. chimborazo chimborazo NHM 1969.37.72; O. chimborazo jamesonii NHM 1925.12.24.66, unnumbered; O. melanogaster NHM 1946.49.405; O. adela NHM 1902.3.13.2009; O. cyanolaemus MECN 9616, MECN 9617, MECN 9618; O. stolzmanni SNM 75569, SNM 75570, SNM 75571. Lower row, left to right: O. estella NHM 1902.3.13.1998, NHM 1902.3.13.1995, unnumbered, NHM 87.3.2.366, unnumbered; O. cyanolaemus MECN 9616, MECN 9617, MECN 9618; 0. stolzmanni NHM 1912.7.1.58, NHM 1902.3.13.2004; O. melanogaster NHM 1946.49.399, NHM 1946.49.401, NHM 1946.49.405, NHM 1946.49.398, NHM 1948.6.5, NHM 1948.6.6. 




APPENDIX FIGURE 11. Ventral view of females of 7 Oreotrochilus taxa photographed at MECN, NMH, and SNM. Upper row, left to right: O. chimborazo chimborazo unnumbered, NHM 97.11.12.87, NHM 1969.37.72, unnumbered, NHM 87.3.14.70, NHM 87.3.22.363, NHM 1902.3.13.2001; O. chimborazo jamesonii NHM 1938.12.20.213, unnumbered, unnumbered, unnumbered, NHM 1925.12.24.66, NHM 97.11.12.90, NHM 1953.68.249, NHM 1902.3.13.2003; O. leucopleurus SNM 87303, SNM 75820, SNM 87302, SNM 75823. Middle row, left to right: O. stolzmanni NHM 1912.7.1.58, NHM 1902.3.13.2004; O. estella NHM 87.3.2.366, NHM 1902.3.13.1999; O. leucopleurus NHM 99.1.27.147, unnumbered; O. chimborazo jamesonii NHM 1925.12.24.66, unnumbered; O. chimborazo chimborazo NHM 1969.37.72; O. melanogaster NHM 1946.49.405; O. adela NHM 1902.3.13.2009; O. cyanolaemus MECN 9616, MECN 9617, MECN 9618. Lower row, left to right: O. estella NHM 1902.3.13.1998, NHM 1902.3.13.1995, unnumbered, NHM 87.3.2.366, unnumbered; O. cyanolaemus MECN 9616, MECN 9617, MECN 9618; O. stolzmanni NHM 1912.7.1.58, NHM 1902.3.13.2004; O. melanogaster NHM 1946.49.399, NHM 1946.49.401, NHM 1946.49.405, NHM 1946.49.398, NHM 1948.6.5, NHM 1948.6.6. 

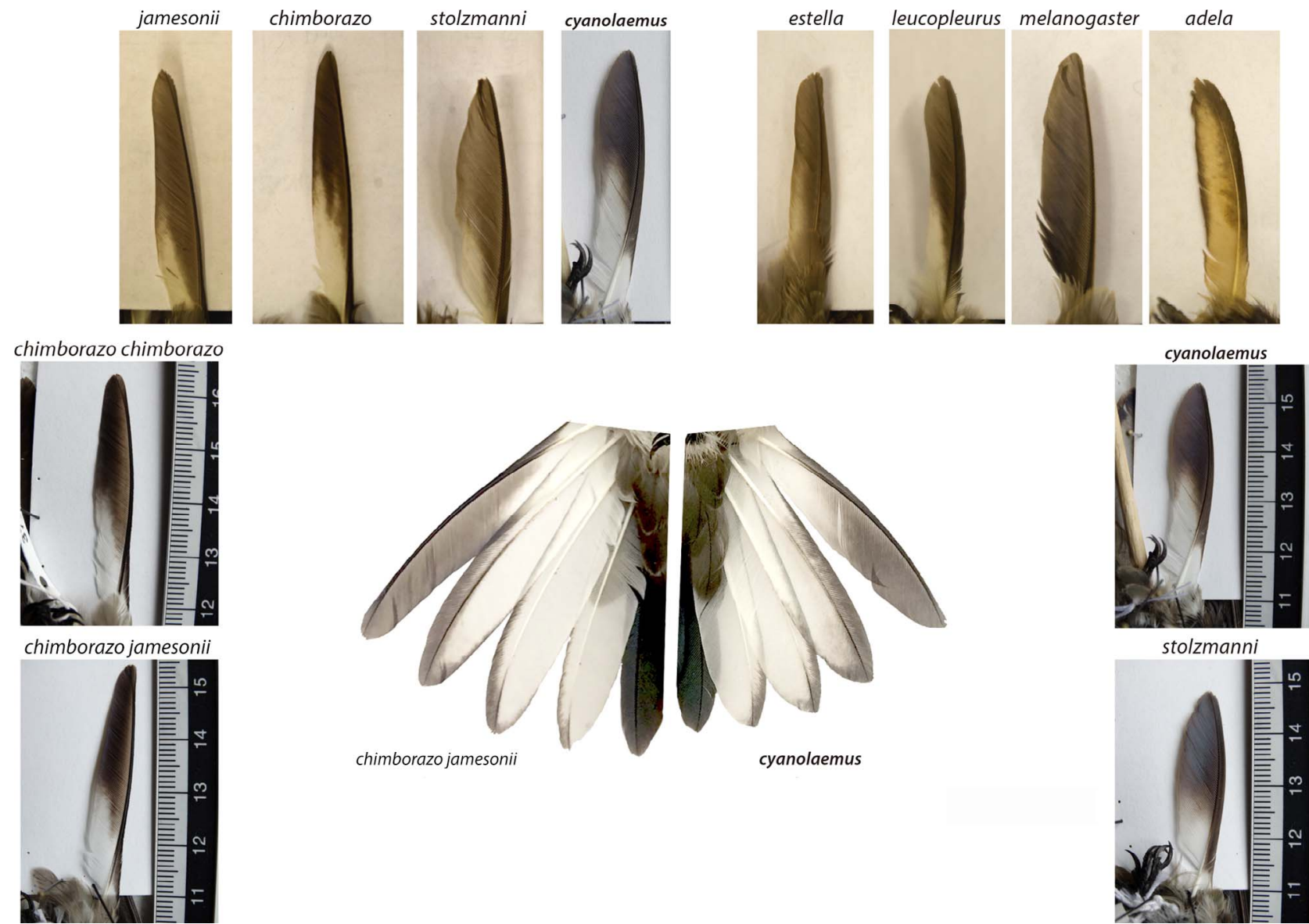

stolzmanni

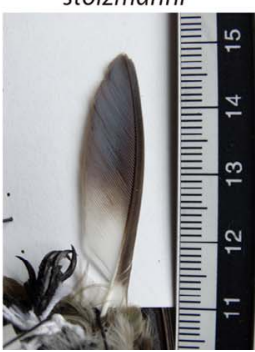

APPENDIX FIGURE 12. Outermost rectrices of males of 7 Oreotrochilus taxa photographed at MECN, NMH, and SNM. Upper row, left to right: O. chimborazo jamesonii unnumbered, O. chimborazo chimborazo unnumbered, O. stolzmanni NHM 1912.7.1, O. cyanolaemus MECN 9615, O. estella NHM 87.3.22.367, O. leucopleurus NHM 1902.3.13.2006, O. melanogaster NHM 87.3.22.376, 0. adela NHM 1902.3.13.2010. Lower left: O. chimborazo chimborazo MECN 6585, O. chimborazo jamesonii MECN 1071. Lower right: O. cyanolaemus MECN 9615, O. stolzmanni MECN 6458. 
cyanolaemus
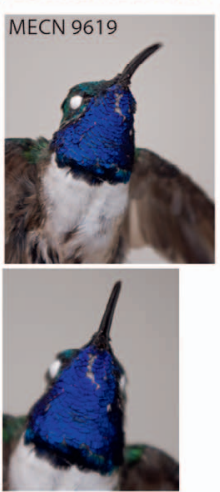

stolzmanni
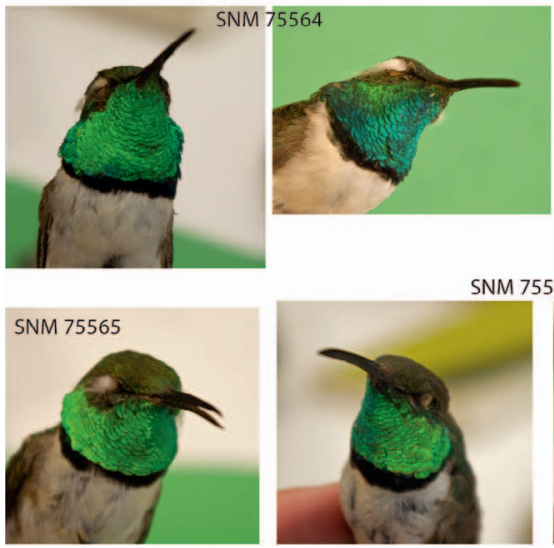

MECN 9615
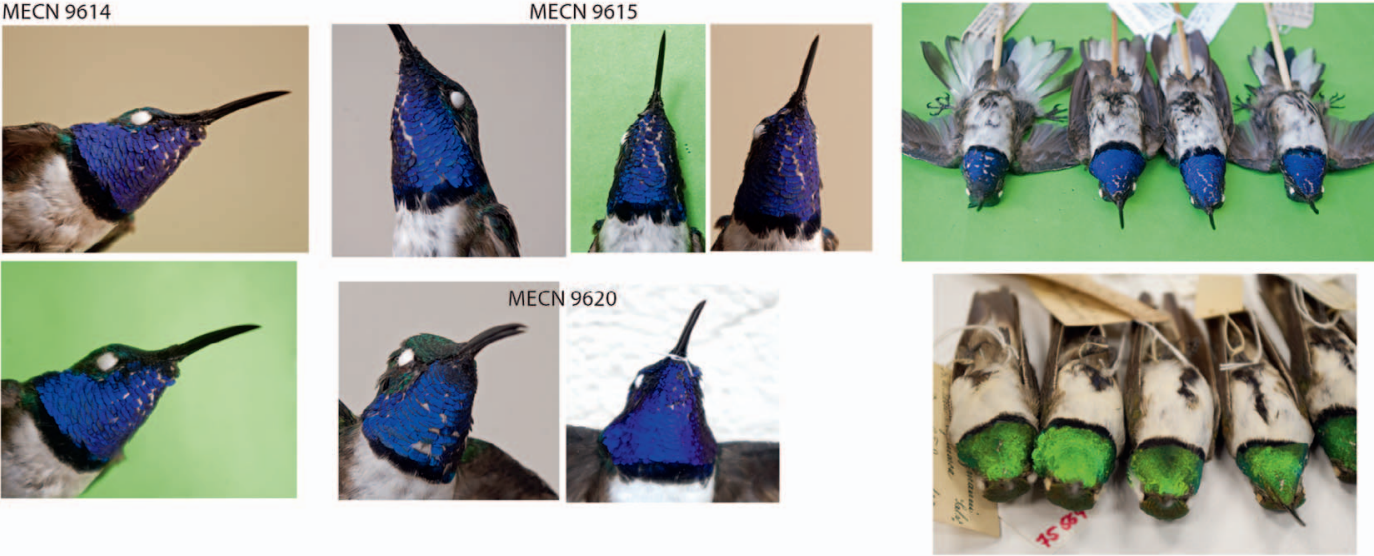

La Libertad
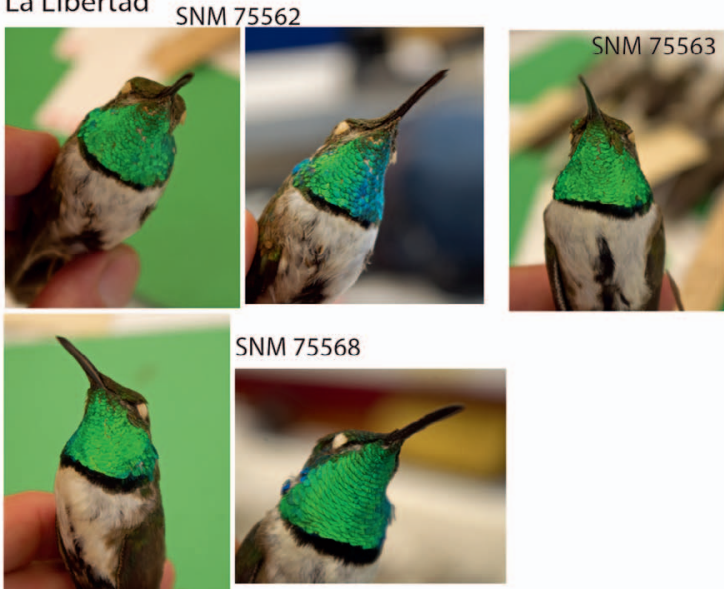

SNM 75568
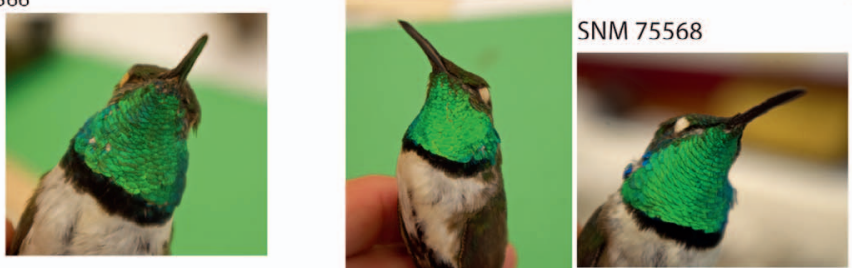

APPENDIX FIGURE 13. Oreotrochilus cyanolaemus and O. stolzmanni specimens photographed at MECN, NMH, and SNM.

APPENDIX C. Samples included in the phylogenetic analyses of species in the genus Oreotrochilus (MECN $=$ Museo Ecuatoriano de Ciencias Naturales; QCAZ = Museo de Zoología, Pontificia Universidad Católica del Ecuador; LSUMZ = Louisiana State University, Museum of Natural Sciences; ANSP = Academy of Natural Sciences Philadelphia; MSB = Museum of Southwestern Biology; Cornell University Museum of Vertebrates; $b p=$ base pairs in the sequence).

\begin{tabular}{|c|c|c|c|c|}
\hline Tissue number & Species & Locality & Accession number & $\mathrm{bp}$ \\
\hline MECN 9614 & O. cyanolaemus & Ecuador: El Oro; Cerro Arcos & MH543324 & 1041 \\
\hline MECN 9617 & O. cyanolaemus & Ecuador: El Oro; Cerro Arcos & MH543325 & 1041 \\
\hline MECN 9615 & O. cyanolaemus & Ecuador: El Oro; Cerro Arcos & MH543326 & 1041 \\
\hline MECN 9616 & O. cyanolaemus & Ecuador: El Oro; Cerro Arcos & MH543327 & 1041 \\
\hline QCAZ 3868 & O. stolzmanni & Ecuador: Zamora; Cordillera de Las Lagunillas & KU600118 & 872 \\
\hline QCAZ 3901 & O. stolzmanni & Ecuador: Zamora; Cordillera de Las Lagunillas & KU600119 & 872 \\
\hline ANSP 19518 & O. stolzmanni & Ecuador: Zamora; Cordillera de Las Lagunillas & KJ602272 & 1041 \\
\hline ANSP 19519 & O. stolzmanni & Ecuador: Zamora; Cordillera de Las Lagunillas & KJ602273 & 505 \\
\hline QCAZ 4159 & O. chimborazo chimborazo & Ecuador: Carchi; Reserva Ecológica El Ángel & KU600169 & 872 \\
\hline QCAZ 3783 & O. chimborazo jamesonii & Ecuador: Chimborazo; Cunungyacu & KU600131 & 872 \\
\hline QCAZ 3782 & O. chimborazo jamesonii & Ecuador: Azuay; near Miguir & KU600144 & 872 \\
\hline MSB:Bird:31543 & O. melanogaster & Peru: Lima; Carampoma & KJ619587 & 1041 \\
\hline LSUMZ B2077 & O. melanogaster & Peru: Lima; $\sim 13$ road km W Milloc & GU166854 & 1041 \\
\hline LSUMZ B103835 & O. estella & $\begin{array}{l}\text { Peru: Ayacucho; Pampa Galeras, } 25 \text { km } \\
\text { WNW Puquio }\end{array}$ & AY830507 & 1041 \\
\hline $\begin{array}{l}\text { CUMV Bird } 55860 \\
\text { Outgroup }\end{array}$ & O. leucopleurus & Argentina: Jujuy; Volcán & KX781714 & 564 \\
\hline LSUMZ B8376 & Ramphomicron microrhynchum & $\begin{array}{l}\text { Peru: Pasco; Millpo, E Tambo de Vacas on } \\
\text { Pozuzo-Chaglla trail }\end{array}$ & EU042587 & 1041 \\
\hline LSUMZ B6277 & Chalcostigma herrani & Ecuador: Pichincha & EU042536 & 1041 \\
\hline
\end{tabular}



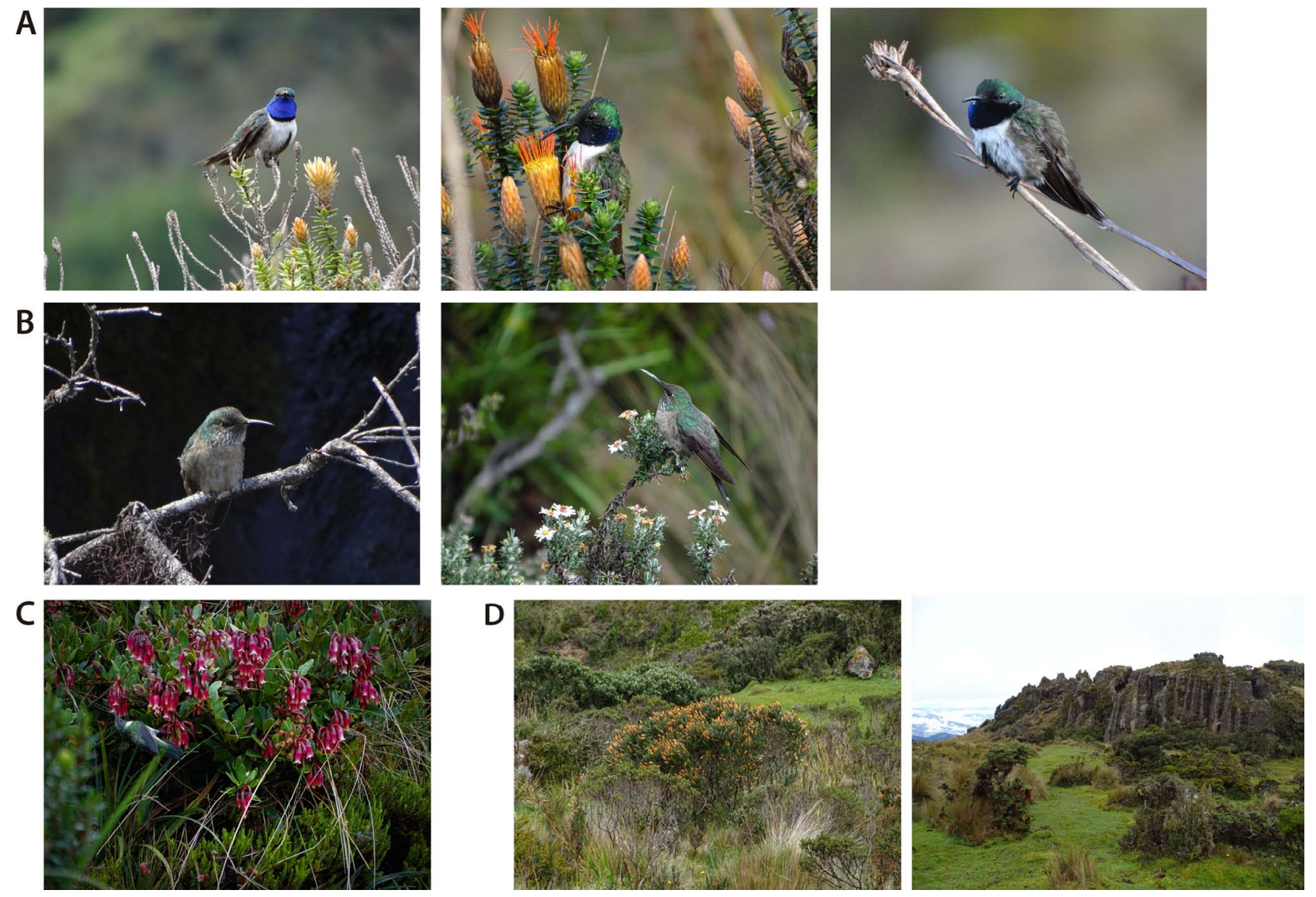

APPENDIX FIGURE 14. Oreotrochilus cyanolaemus photographed during fieldwork (May-July 2017 and April 2018), El Oro and Loja provinces, southwest Ecuador (F. Sornoza-Molina): (A) adult male, (B) female, (C) immature male, (D) preferred feeding plant and general habitat. Additional photographic and acoustic material is uploaded in Macaulay Library, Xeno-Canto, and Internet Bird Collection. 